3. From: (Originating Organization) Plant Engineering

Plant Engineering

5. Proj./Prog./Dept./Div.:

Waste Management

8. Originator Remarks:

Key Words: Double Shell Tank. Pumping Plan. Emergency Plan, Transfer Routes, Tank Leakage. Emergency Transfer. Leak Detection

11. Receiver Remarks:
6. Cog. Engr.:

D. W. Reberger
Page 1 of 1 1. EDT $607 \overline{537}$

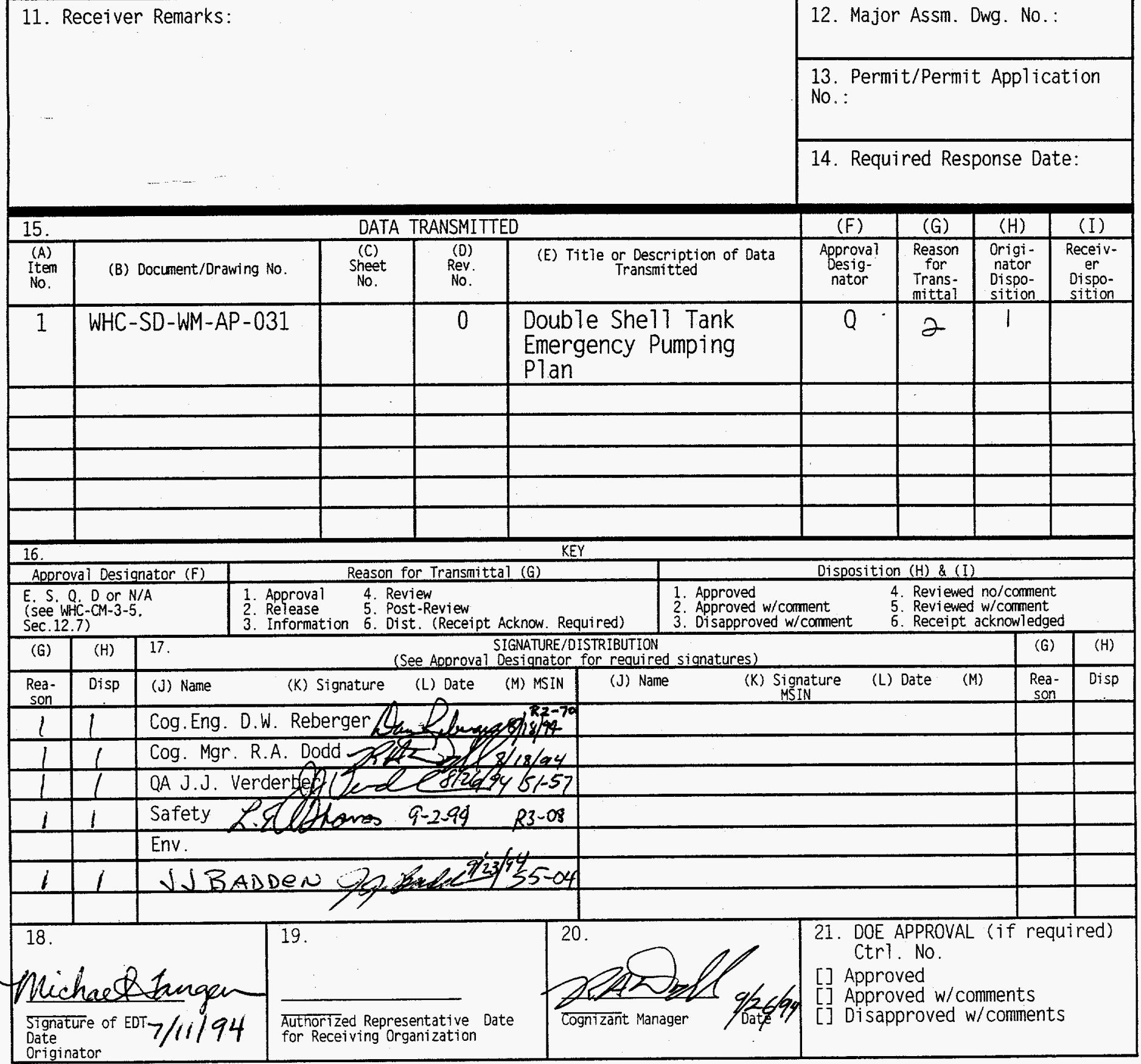

BD-7400-172-2 (04/94) GEF097 


\section{DISCLAIMER}

Portions of this document may be illegible in electronic image products. Images are produced from the best available original document. 


\section{RELEASE AUTHORIZATION}

\section{Document Number: WHC-SD-WM-AP-031, REV.0}

Document Title: Double Shell Tanks Emergency Pumping Plan

Release Date: $\quad$ September 23, 1994

This document was reviewed following the procedures described in WHC-CM-3-4 and is:

APPROVED FOR PUBLIC RELEASE

WHC Information Release Administration Specialist:

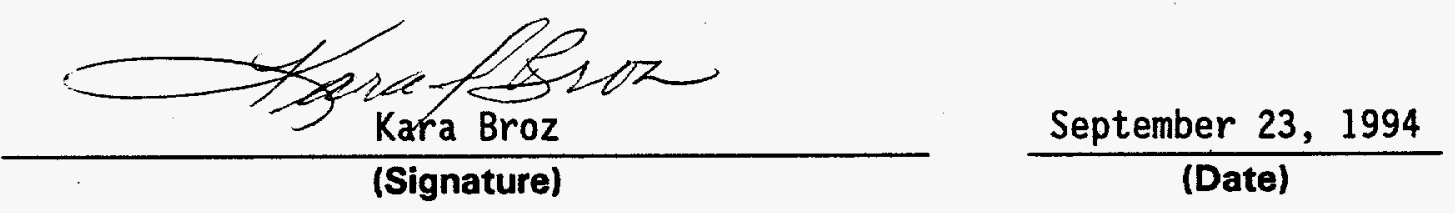




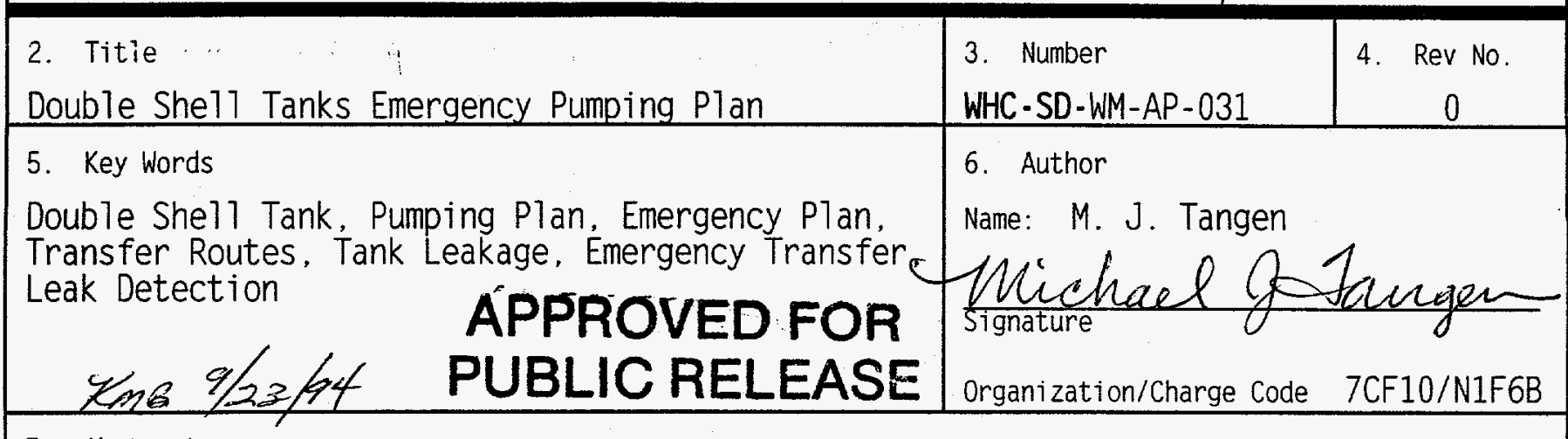

7. Abstract

This document contains general information about necessary actions to be taken upon the discovery of a leak in one of the double shell tanks. Transfer routes. leak detection equipment. pump information, and hydraulic diagrams are included in the document to aid the transfer process. Watch list tanks are also identified.

8. RURPOSE AND USE OF DOCUMENT - This document was prepared for use within the U.S. Department of Energy and its contractors. It is to be used only to perform, direct, or integrate work under U.S. Separtment of Energy contracts. Fhis document is not approved for public release until rexlewed.

PATENT STATUS - This document copy, since it is transmitted in advance of patent clance, is made available in confidence solely for use in performance of work under contracts with the y.5. Department of Energy. This document is not to bo published nor its contents otherwise disseminates or used for purposes other than specified above before patent approval for such release or use has been secured, upon request, from the Patent Csunsel. 甘.S. Department of Energy Field Office, Richland, WA.

DISCLAIMER - This report was prepared as an account of work sponsored by an agency of the United States Government. Neither the United States Government nor any agency thereof, nor any of their employees, nor any of their contractors, subcontractors or their employees, makes any warranty, express or implied, or assumes any legal liability or responsibility for the accuracy, completeness, or any third party's use or the results of such use of any information. apparatus, product, or process disclosed, or represents that its use would not infringe privately owned rights. Reference herein to any specific commercial product, process, or service by trade name, trademark. manufacturer, or otherwise, does not necessarily constitute or imply its endorsement, recommendation, or favoring by the United States Government or any agency thereof or its contractors or subcontractors. The views and opinions of authors expressed herein do not necessarily state or reflect those of the United States Government or any agency thereof.
10.

RELEASE STAMP

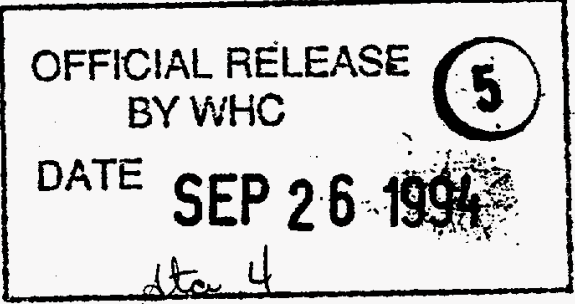


WHC-SD-WM-AP-031 REV 0

\title{
DOUBLE SHELL TANKS \\ EMERGENCY PUMPING PLAN
}

\author{
Michael J. Tangen \\ East Tank Farms Systems Engineering
}
Prepared for the United States Department of Energy Westinghouse Hanford Company P. O. Box 1970
Richland, WA 99352




\section{DOUBLE SHELL TANKS}

EMERGENCY PUMPING PLAN

EXECUTIVE SUMMARY . . . . . . . . . . . . . . . . . . . . 2

1.0 INTRODUCTION . . . . . . . . . . . . . . . . . . 4

2.0 OBJECTIVE . . . . . . . . . . . . . . . . . . . 4

3.0 SCOPE . . . . . . . . . . . . . . . . . . 4

4.0 EMERGENCY PLAN DEVELOPMENT . . . . . . . . . . . . . ..... 4

4.1 DOE Orders . . . . . . . . . . . . . . . . . 5

4.2 Leak Detection................... . . 5

4.3 Transfer Routes . . . . . . . . . . . . . . . . . . . . 6

4.4 Compatibility ... . . . . . . . . . . . . . . . . 7

4.5 Pressure Testing . . . . . . . . . . . . . . . . . . 77

4.6 Head Loss Calculations . . . . . . . . . . . . . . . . . . . . 7

4.7 Salt Well Jet Pumping . . . . . . . . . . . . . . . . . . 8

4.8 Waste in the Annulus . . . . . . . . . . . . . . . . . 9

4.9 Flushing Procedures . . . . . . . . . . . . . . . 9

4.10 Recommendations . . . . . . . . . . . . . . . . . . . . 11

APPENDIX A: TRANSFER DATA, AN FARM . . . . . . . . . . . . . . 12

Transfer Routes . . . . . . . . . . . . . . . . . . . . . 12

Valve Checklists ................... . . . 14

Leak Detection Equipment . . . . . . . . . . . . . . . . . . . 23

Hydraulic Diagrams, AN Farm . . . . . . . . . . . . . . . . . . 27

APPENDIX B: TRANSFER DATA, AW FARM . . . . . . . . . . . . . 30

Transfer Routes . . . . . . . . . . . . . . . . . . . . . . . 30

Valve Checklists . . . . . . . . . . . . . . . . . . . . 32

Leak Detection Equipment . . . . . . . . . . . . . . . . . . . . . 41

Hydraulic Diagrams, AW Farm . . . . . . . . . . . . . . . . . . 43

APPENDIX C: TRANSFER DATA, AP FARM . . . . . . . . . . . . . . . . 47

Transfer Routes . . . . . . . . . . . . . . . . . . 47

Valve Checklists . . . . . . . . . . . . . . . . . . 49

Leak Detection Equipment . . . . . . . . . . . . . . . . . . . . . 56

Hydraul ic Diagram, AP Farm . . . . . . . . . . . . . . . . . . . . 58

APPENDIX D: TRANSFER DATA, AY FARM . . . . . . . . . . . . 60

Transfer Routes . . . . . . . . . . . . . . . . . . . 60

Valve Checklists . . . . . . . . . . . . . . . 61

Leak Detection Equipment . . . . . . . . . . . . . . . . . . . 64

Hydraul ic Diagrams, AY Farm . . . . . . . . . . . . . . . . . . . . .65 
WHC-SD-WM-AP-031 REV 0

APPENDIX E: TRANSFER DATA, SY FARM . . . . . . . . . . . . 67 Transfer Routes . . . . . . . . . . . . . . . 67 Valve Checklists . . . . . . . . . . . . . . . . . . . . . 68 Leak Detection Equipment . . . . . . . . . . . . . . . . . . . . . 71 Hydraulic Diagrams, SY Farm . . . . . . . . . . . . . . . . . . . 73

APPENDIX F: Head Loss Calculations . . . . . . . . . . . . . . 76

APPENDIX G: Results of Head Loss Calculations (Currently Installed Pumps) . . . . . . . . . . . . . . . . 78

APPENDIX H: Calculated Head Losses for Standard Pipe Flow Rates . . . 79

APPENDIX I: Calculated and Measured Head Loss vs. Flow Values for 102-AN and 104-AN ............. . 80

APPENDIX J: Other Interconnected Tanks . . . . . . . . . . . . . 82 
WHC-SD-WM-AP-031 REV 0

This page intentionally left blank. 
WHC-SD-WM-AP-031 REV 0

\section{DOUBLE SHELL TANKS EMERGENCY PUMPING PLAN EXECUTIVE SUMMARY}

In the event that one of the double shell waste storage tanks begins to leak, a group of emergency action plans for the transfer of the waste from that tank to a designated receiver tank has been developed and incorporated into a single procedure. The tanks included in this plan are those located in AN, AP, AW, AY, and SY farms, with TK-104-AP being named as the designated receiver tank. The $A Z$ tank farm has been purposely omitted at this time due to the high heat waste considerations. Emergency pumping on AZ farm wi 11 be included in this report at a later date.

Currently, a 11 of the tanks included in these farms are equipped with transfer pumps with the exception of TK-107-AN and TK-101-SY. Due to the distance and special cross-site pumping considerations involved in the transfers from SY farm, procedures involving these tanks will require the shuffling of waste from TK-102-AY to make these transfers possible. A fluid analysis performed on the transfer routes involved in this plan (Appendix $F$ ) has been used to determine that all of the currently installed pumps are adequate to perform the transfer operations as required. Expected head loss values at standard flow rates for all transfer routes are also included in this procedure, which wi 11 aid in the sizing of pumps for the two open tanks.

Hydraulic diagrams have been drawn for each farm in an effort to determine the best method of flushing the transfer lines once the transfer is complete. It is hoped that the amount of water flushed back into the leaking tank can be kept at a minimum to avoid additional leakage. If water must be sent into the tank, efforts to maintain the waste level below the leak level should be made. The hydraulic diagrams for each farm are included in their respective appendices, A through $E$.

The results of the data acquisition and analysis have led to the following conclusions: 
WHC-SD-WM-AP-031 REV 0

1. Waste from tanks 101 and 103-SY wi11 be transferred to tank 102-SY after the waste from 102-SY is sent cross-site to 102-AY. Waste from 102-AY would first be sent to 104-AP.

2. Calculations for the transfer pumps currently installed in tanks 102 and 104-AN initially led to the conclusion that the pumps were inadequate to transfer the tank contents to tank 104AP. A comparison of the calculated data with the measured performance data for these pumps, however, shows that the pump flow rates will be slower than the rated value, but will still be sufficient. A graph of the performance data and the theoretical data, illustrating the expected performance of the pumps, appears in Appendix I of this report. Both of these pumps, which have identical rating and performance data, will be able to complete the transfers to tank 104-AP at flow rates between 110 and 125 galions per minute.

3. Tanks 107-AN and 101-SY have no transfer pumps current7y installed in their primary pump pits. In the event of a leak. transfer pumps will need to be installed to remove the waste from the primary tanks.

A11 decisions and courses of action described in this document are in compliance with established safety and regulatory procedures. Several of the tanks are designated watch 7 ist tanks for hydrogen/flammable gas (101-SY, 103SY, 101-AW, 103-AN, 104-AN, and 105-AN), and therefore have additional regulations. According to OSD-T-151-00030, transfers out of these tanks require written approval by Tank Waste Remediation Systems, Waste Tanks Safety Assurance, and the DOE. Any transfers into these tanks require the written approval of the Secretary of Energy. 
WHC-SD-WM-AP-031 REV 0

\subsection{INTRODUCTION}

At the request of the Department of Energy (DOE), a formal plan for the emergency transfer of waste from a leaking double shell tank to a designated receiver tank has been developed. This plan is in response to the priority 2 safety issue "Response to a leaking double-shell tank" in the DOE Report to Congress. 1991. The plan includes the tanks in four of the east tank farms and one of the west farms. The background information and supporting calculations used for the creation of the emergency plan are discussed in this document.

\subsection{OBJECTIVE}

This plan wi11 facilitate the process of transferring waste from leaking double shell tanks. By having a pre-written document, tank farm operations will be able to initiate the waste transfers much more quickly than before while maintaining high levels of safe operation.

\subsection{SCOPE}

The scope of this document is all of the double shell tanks in the AN, AP. AW. AY, and SY farms. The transfer lines, flush pits, and valve pits involved in the transfer of waste between these farms are also included in the scope. Due to the storage of high heat waste, AZ farm is excluded at this time.

\subsection{EMERGENCY PLAN DEVELOPMENT}

Development of the emergency plan for the double shell tanks involved several steps. First of a11, transfer routes for the transfer of waste from each tank needed to be determined. An inventory of the existing transfer pumps followed. leading to an analysis of fluid flow properties of the transfer lines to assess the ability of the existing equipment to complete the transfers. Once the final set of transfer routes was determined, a valve 
WHC-SD-WM-AP-031 REV 0

checklist for each transfer route was established. Finally, the creation of hydraulic diagrams for use in examining flushing procedures was completed.

\subsection{DOE Orders}

According to DOE order 5820.2A, waste may not be stored in a double shel1 tank in which a leak has been detected unless double containment can be maintained. This order states that draining a leaking tank to a level below that of the leak provides acceptable double containment, and hence is the plan of action that has been adopted. The DOE order also states that materials released from the primary tank must be removed within 24 hours, or in as timely a manner as is possible. The creation of the emergency transfer plan will aid tank farm operations in beginning the waste transfers as quickly as possible, in accordance with the DOE guidelines.

\subsection{Leak Detection}

The two methods of leak detection that are used in the double shel1 tanks are the Continuous Air Monitor (CAM) system, and liquid conductivity sensors. The CAM system works by continuously circulating air from the annulus through its filters and monitoring the level of radiation present. Any increases in the radiation level wi1l trigger alarms that indicate a tank breach may have occurred. If the increase in the vent radiation reading is greater than three times the baseline value and the presence of long half-life isotopes is confirmed, then the tank may be considered a suspected leaker. The second detection system, the liquid conductivity sensors, physically detect the leaking material. When liquid waste from the primary tank comes into contact with one of the sensors, the waste completes an electric circuit which triggers an alarm. The CAM system is the more sensitive of the two, and is the primary detection device. The conductivity sensors are primarily used as backup to the CAM system. 
WHC-SD-WM-AP-031 REV 0

\subsection{Transfer Routes}

The initial step taken in evaluating the transfer of waste to tank 104-AP was to define the transfer routes that would be used to perform this task. Identification of transfer routes was done through the use of the routing boards at the shift offices of 200 East and West, as well as by referencing existing transfer procedures for these farms. The routing board was also used to determine the specific valve pit nozzles which complete the transfer routes. Appendices $A$ through $E$ contain a summary of the transfer routes for the tanks involved in this study, organized by farm. In addition, the nozzles that are to be used in each valve pit are listed to aid in the installation of necessary jumpers.

Transfers involving the SY farm are a little more complex than the transfers from the other farms due to the cross-site location of the SY farm. For a 11 SY transfers, the first step wi11 be to transfer the waste from tank 102-AY to tank 104-AP. The waste from tank 102-SY wi11 then be sent cross-site to tank 102-AY using the installed cross-site transfer pump. If necessary, waste from either of the other two SY farm tanks can then be transferred to tank 102-SY.

In the event that tank 104-AP should begin to leak before any other waste is pumped into it, the smal1 amount of waste currently in tank 104-AP wi 11 need to be pumped into one of the other double shell tanks. This transfer should not be very difficult given the relatively small volume being handled, and can be accomplished with existing procedures. With 104-AP thus out of service, however, a new contingency tank wil1 need to be determined, and this emergency plan wi 11 need to be revised accordingly. The same holds true in the event that an emergency transfer is made to tank 104-AP, as that tank wi11 no longer be available as a spare. In this case, the revised plan should also include a route to transfer the waste from tank 104-AP to the newly designated spare tank. 
WHC-SD-WM-AP-031 REV 0

\subsection{Compatibility}

Compatibility tests are performed on the waste in both the supply and receiver tanks before a transfer takes place to make certain that undesirable chemical reactions do not occur. The document "Data Quality Objectives for the Waste Compatibility Program" (WHC-SD-WM-DQD-001, Rev. 0) discusses the criteria used to assess the compatibility of wastes before they are mixed. Most of the transfers discussed in this plan involve moving waste only to TK-104-AP, which contains roughiy 30,000 gallons of a very dilute waste that should pose no compatibility problems. Transfers involving SY farm, however, involve transferring waste into tanks which contain large volumes of high-level waste that may cause a safety concern if mixed.

\subsection{Pressure Testing}

Pressure testing is required on certain transfer lines to make sure that leaking will not occur during the transfer. These lines are defined in OSD-T151-00010, and the pressure testing procedure is discussed in T0-140-170. Pressure testing involves filling the transfer line with water and then pressurizing it with air. The pressure in the line is then monitored for a specified period of time to see if any noticeable drop occurs, which would indicate a leak in the line. The allowed pressure loss for transfer lines is discussed in the documents listed above.

\subsection{Head Loss Calculations}

The head loss calculations for each transfer route are presented in two parts. The first set of calculations represents the head losses expected using the currently installed pumping equipment. The second set of calculations shows the expected head losses for four standard pumping flow rates of 50, 100, 125, and 150 gallons per minute. A detailed explanation of the calculations is presented in Appendix $F$, while tables showing the resulting figures are presented in Appendices $G$ and $H$. It is important to mention that losses due 
WHC-SD-WM-AP-031 REV 0

to components such as elbows and valves have been ignored in these calculations since their contributions to the overall head loss in the pipes are insignificant compared to the other sources of loss. Any losses experienced in the two instances where the flow moves from 2 inch diameter pipes to 3 inch diameter pipes are also comparatively small and are therefore ignored. Both of these sets of calculations incorporate frictional and elevation losses.

Head loss values are calculated.using both laboratory and engineering data in Bernoul1i's equation for pipe flow. Waste material temperatures are assumed to be at an average temperature between 50 and 100 degrees Fahrenheit. Whenever assumptions are warranted, conservative estimates are used. Results are reported in units of feet.

While most of the specific gravity data is available for the tank waste discussed in this report, viscosity data is harder to locate. Based on the known specific gravities for the tank wastes, as well as the fact that the major constituent of the waste is water, values for the viscosities of the tank wastes can be conservatively estimated. Conservative specific gravity values based on the values given for the remainder of the tanks are used for the two tanks which have limited laboratory data on file.

\subsection{Salt We11 Jet Pumping}

The purpose of salt well jet pumping is to remove any interstitial liquid that is trapped between solids in the tank. In the process of salt well jet pumping, a cylindrical screen is inserted into the tank to prevent the solids from clogging the pumping lines. A jet pump working in concert with a centrifugal pump then proceeds to create a circular flow of pumped liquid, part of the liquid priming the pump for the remaining flow. With each cycle, some of the fluid is forced out of the tank, and the rest is recycled into the tank. Pumping continues until a 11 of the interstitial fluid has been forced out of the tank. 
WHC-SD-WM-AP-031 REV 0

Jet pumping in a leaking tank is a very real possibility due to the potential for a leak occurring at or near the bottom of the tank. In the event such a leak should occur, removal of the liquid waste from the solids in the tank will need to be done by salt well jet pumping. Although the flow rates of the jet pumps are very slow (between 0.05 and 4.0 gallons per minute), they are able to transfer waste along the same routes described for the transfer pumps.

Currently, there are no salt well jet pumping systems installed in the double shel1 tanks. In order to prepare the double shell tanks for pumping, salt well screens need to be installed in each tank. Also, jet pump lengths need to be modified depending on the situation in the tank being pumped.

\subsection{Waste in the Annulus}

Once a leak has been detected, the waste in the annulus will need to be removed. The plan adopted is to pump this waste back into the primary tank. Waste will be removed from the primary tank at a much greater rate than it will be leaking into the annulus, making this procedure valid. Currently. most of the tanks covered by this plan do not have annulus pumps installed. Tanks 107-AN, 103-AP, and 101-AY each have an annulus pump insta7led that could serve as the spare for their respective farms. AW and SY farms have no annulus pumps present at this time.

\subsection{Flushing Procedures}

After all waste transfer operations are complete, the equipment and transfer lines used must be flushed to prevent solids and salts from settling out of the residual waste. Typically, water from one of the existing flush pits is routed into the transfer lines, flushing residual waste from the transfer lines either forward into the receiver tank or back into the supply tank. A concern regarding this particular set of transfers, however, is sending flush water into the leaking tanks, knowing that it will end up leaking into the annulus. The exception is the case where the leaking tank is pumped to a 
WHC-SD-WM-AP-031 REV 0

level below the leak, and addition of the flush water will not raise the waste level above the level of the leak.

Any flushing that occurs in the east tank farms will involve the use of the 241-AW flush pit. The hydraulic schematics included in this document (Appendices A through E) illustrate where the water from the 241-AW flush pit will enter the transfer routes, and in which directions the water wi 11 have a tendency to flow. The only water that would enter the leaking tank would be drainback from the portion of the transfer line which is higher in elevation than the tank. Since only enough water required to fill the volume of the transfer line is required for flushing the line, the amount of water that would flow into the damaged tank would be minimal.

Another option for flushing transfer lines is to use the method described in procedure T0-020-705. Flush Saltwe11 Jet Pump Systems and Transfer Routes. This procedure details the process of connecting a water truck to the transfer route at the supply tank and pumping water from there to the receiver tank. The water truck has a pump which enables the flushing. A small amount of water (approximately 20 gallons) is also used to flush the pumping equipment in the supply tank. Using a water truck will not prevent the need for the water in the elevated portion of the transfer line to be drained into the leaking tank.

Using the second method involves incorporating the water truck into the transfer route and isolating the supply tank. This can be accomplished with either a jumper change or the connection of the water truck hose to a flush connection in the supply tank pump pit, thereby completely removing the supply tank from the transfer route. For most instances, the flushing procedure wi11 involve removing the jumper used in the pump pit during the transfer and attaching the water hose to the appropriate nozzle. 


\subsection{Recommendations}

The most time-consuming portion of the transfer procedures discussed in this plan is the installation of necessary equipment that is not already in place. In the event a leak should be confirmed in one of the tanks, an emergency transfer will be expedited if tank farm personnel are able to begin the process without spending time on equipment set-up. Nearly all of the tanks in the five farms covered in this plan do not have annulus pumps currently installed, and two of the tanks do not have transfer pumps installed. Although pump installation is outside of the scope of this document, it is recommended that this issue be addressed in the interest of being better prepared for an emergency transfer. 
WHC-SD-WM-AP-031 REV 0

APPENDIX A: TRANSFER DATA, AN FARM

\section{Transfer Routes}

\section{TK-101-AN}

Route: Transfer Pump (01A Pit) to SN-261

SN-261 to 241-AN-B Valve Pit

SN-260 from 241-AN-B Valve Pit to TK-102-AZ 02B Pit

SN-600 from TK-102-AZ 02B Pit to 241-AX-A Valve Pit

$S N-214 / 201$ from 241-AX-A Valve Pit to 241-A-A Valve Pit

SN-220 from 241-A-A Valve Pit to 241-AW-A Valve Pit

SN-267 from 241-AW-A Valve Pit to TK-102-AW

SN-609 from TK-102-AW to 241-AP Valve Pit

SN-614 from 241-AP Valve Pit to TK-104-AP

Jumpers: Nozzle R-15 to Nozzle R-2 in AN-B Valve Pit

Nozzle U-7 to Nozzle U-5 in 102-AZ 02B Pit

Nozzle $L-16$ to $L-1$ in $A X-A$ Valve Pit

Nozzle $L-1$ to $L-2$ in A-A Valve Pit

Nozzle $L-2$ to $L-1$ in AW-A Valve Pit

Nozzle $\mathrm{J}$ to Nozzle $V$ in TK-102-AW Pit

Nozzle 14 to Nozzle 20 in 241-AP Valve Pit

\section{TK-102-AN}

Route: Transfer Pump (02A Pit) to SN-262

SN-262 to 241-AN-B Valve Pit

Continue following route for TK-101-AN

Jumpers: Nozzle R-16 to Nozzle R-2 in AN-B Valve Pit Continue as per TK-101-AN

TK-103-AN

Route: Transfer Pump (O3A Pit) to SN-263

$\mathrm{SN}-263$ to $241-\mathrm{AN}-\mathrm{B}$ Valve Pit

Continue following route for TK-101-AN

Jumpers: Nozzle R-14 to Nozzle R-2 in AN-B Valve Pit Continue as per TK-101-AN

\section{TK-104-AN}

Route: Transfer Pump (04A Pit) to SN-264

SN-264 to $241-A N-A$ Valve Pit

SN-268 from 241-AN-A Valve Pit to 241-AN-B Valve Pit Continue following route for TK-101-AN 
Jumpers: Nozzle L-15 to Nozzle L-19 in AN-A Valve Pit Nozzle R-19 to Nozzle R-2 in AN-B Valve Pit

Continue as per TK-101-AN

\section{TK-105-AN}

Route: Transfer Pump (05A Pit) to SN-265

SN-265 to 241-AN-A Valve Pit

SN-268 from 241-AN-A Valve Pit to 241-AN-B Valve Pit

Continue following route for TK-101-AN

Jumpers: Nozzle L-16 to Nozzle L-19 in AN-A Valve Pit

Nozzle R-19 to Nozzle R-2 in AN-B Valve Pit

Continue as per TK-101-AN

\section{TK-106-AN}

Route: Transfer Pump (06A Pit) to SN-266

SN-266 to 241-AN-A Valve Pit

SN-268 from 241-AN-A Valve Pit to 241-AN-B Valve Pit

Continue following route for TK-101-AN

Jumpers: Nozzle L-14 to Nozzle L-19 in AN-A Valve Pit Nozzle R-19 to Nozzle R-2 in AN-B Valve Pit

Continue as per TK-101-AN

\section{TK-107-AN}

Route: Transfer Pump (07A Pit) to SN-267

SN-267 to 241-AN-A Valve Pit

SN-268 from 241-AN-A Valve Pit to 241-AN-B Valve Pit Continue following route for TK-101-AN

Jumpers: Nozzle L-1 to Nozzle L-19 in AN-A Valve Pit Nozzle R-19 to Nozzle R-2 in AN-B Valve Pit

Continue as per TK-101-AN 
Valve Checklists

TK-101-AN TO TK-104-AP VALVE POSITION CHECKLIST

\begin{tabular}{|c|c|}
\hline Valve Description & Valve Position \\
\hline \hline 01A (AN-01A Central Pit) & $\begin{array}{c}\text { Route flow from pump to Nozzle A, } \\
\text { Block flow to Nozzle G }\end{array}$ \\
\hline B-18 (241-AN-B Valve Pit) & OPERATE \\
\hline B-16 (241-AN-B Valve Pit) & $\begin{array}{c}\text { Route flow from Nozzle R-15 to Valve } \\
\text { B-15, Block flow to Nozzle R-14 }\end{array}$ \\
\hline B-15 (241-AN-B Valve Pit) & $\begin{array}{c}\text { Route flow from Valve B-16 to Valve } \\
\text { B-13, Block flow to Nozzle R-16 }\end{array}$ \\
\hline B-14 (241-AN-B Valve Pit) & CLOSED \\
\hline B-13 (241-AN-B Valve Pit) & $\begin{array}{c}\text { Route flow from Valve B-15 to Nozzle } \\
\text { R-2, Block flow to Nozzle R-19 }\end{array}$ \\
\hline Continue with AN Common Valving & \\
\hline Instructions & \\
\hline & \\
\hline
\end{tabular}


WHC-SD-WM-AP-031 REV 0

TK-102-AN TO TK-104-AP VALVE POSITION CHECKLIST

\begin{tabular}{||c|c||}
\hline Valve Description & Valve Position \\
\hline 02A (AN-02A Central Pit) & $\begin{array}{c}\text { Route flow from pump to Nozzle A. } \\
\text { Block flow to Nozzle G }\end{array}$ \\
\hline B-18 (241-AN-B Valve Pit) & OPERATE \\
\hline B-16 (241-AN-B Valve Pit) & $\begin{array}{c}\text { Route flow from Nozzle R-15 to } \\
\text { Nozzle R-14, Block flow to Valve B- } \\
\text { 15 }\end{array}$ \\
\hline B-15 (241-AN-B Valve Pit) & $\begin{array}{c}\text { Route flow from Nozzle R-16 to Valve } \\
\text { B-13, Block flow to Valve B-16 }\end{array}$ \\
\hline B-14 (241-AN-B Valve Pit) & CLOSED \\
\hline B-13 (241-AN-B Valve Pit) & $\begin{array}{c}\text { Route flow from Valve B-15 to Nozzle } \\
\text { R-2. Block flow to Nozzle R-19 }\end{array}$ \\
\hline Continue with AN Common Valving & \\
\hline Instructions & \\
\hline & \\
\hline
\end{tabular}


WHC-SD-WM-AP-031 REV 0

TK-103-AN TO TK-104-AP VALVE POSITION CHECKLIST

\begin{tabular}{|c|c|}
\hline Valve Description & Valve Position \\
\hline \hline 03A (AN-03A Central Pit) & $\begin{array}{c}\text { Route flow from pump to Nozzle A, } \\
\text { Block flow to Nozzle G }\end{array}$ \\
\hline B-18 (241-AN-B Valve Pit) & OPERATE \\
\hline B-16 (241-AN-B Valve Pit) & $\begin{array}{c}\text { Route flow from Nozzle R-14 to Valve } \\
\text { B-15. Block flow to Nozzle R-15 }\end{array}$ \\
\hline B-15 (241-AN-B Valve Pit) & $\begin{array}{c}\text { Route flow from Valve B-16 to Valve } \\
\text { B-13. Block flow to Nozzle R-16 }\end{array}$ \\
\hline B-14 (241-AN-B Valve Pit) & CLOSED \\
\hline B-13 (241-AN-B Valve Pit) & $\begin{array}{c}\text { Route flow from Valve B-15 to Nozzle } \\
\text { R-2. Block flow to Nozzle R-19 }\end{array}$ \\
\hline Continue with AN Common Valving & \\
\hline Instructions & \\
\hline & \\
\hline
\end{tabular}


TK-104-AN TO TK-104-AP VALVE POSITION CHECKLIST

\begin{tabular}{|c|c|}
\hline Valve Description & Valve Position \\
\hline 04A (AN-04A Central Pit) & $\begin{array}{c}\text { Route flow from pump to Nozzle A, } \\
\text { Block flow to Nozzle G }\end{array}$ \\
\hline A-18 (241-AN-A Valve Pit) & OPERATE \\
\hline A-16 (241-AN-A Valve Pit) & $\begin{array}{l}\text { Route flow from Nozzle } L-15 \text { to valve } \\
\text { A-15, Block flow to Nozzle } L-14\end{array}$ \\
\hline A-15 (241-AN-A Valve Pit) & $\begin{array}{l}\text { Route flow from valve A-16 to valve } \\
\text { A-13, Block flow to Nozzle } L-16\end{array}$ \\
\hline A-14 (241-AN-A Valve Pit) & CLOSED \\
\hline A-13 (241-AN-A valve Pit) & $\begin{array}{l}\text { Route flow from Valve A-15 to Nozzle } \\
L-19 \text {, Block flow to Nozzle } L-1\end{array}$ \\
\hline B-18 (241-AN-B Valve Pit) & OPERATE \\
\hline B-16 (24I-AN-B Valve Pit) & $\begin{array}{c}\text { Route flow from Nozzle R-14 to } \\
\text { Nozzle R-15, Block flow to Valve B- } \\
15\end{array}$ \\
\hline B-15 (241-AN-B Valve Pit) & $\begin{array}{l}\text { Route flow from Valve B-16 to Nozzle } \\
\text { R-16. BTock flow to Valve B-13 }\end{array}$ \\
\hline B-14 (241-AN-B valve Pit) & CLOSED \\
\hline B-13 (241-AN-B Valve Pit) & $\begin{array}{l}\text { Route flow from Nozzle R-19 to } \\
\text { Nozzle R-2, Block flow to Valve B-15 } \\
\end{array}$ \\
\hline $\begin{array}{c}\text { Continue with AN Common Valving } \\
\text { Instructions }\end{array}$ & \\
\hline
\end{tabular}


WHC-SD-WM-AP-031 REV 0

TK-105-AN TO TK-104-AP VALVE POSITION CHECKLIST

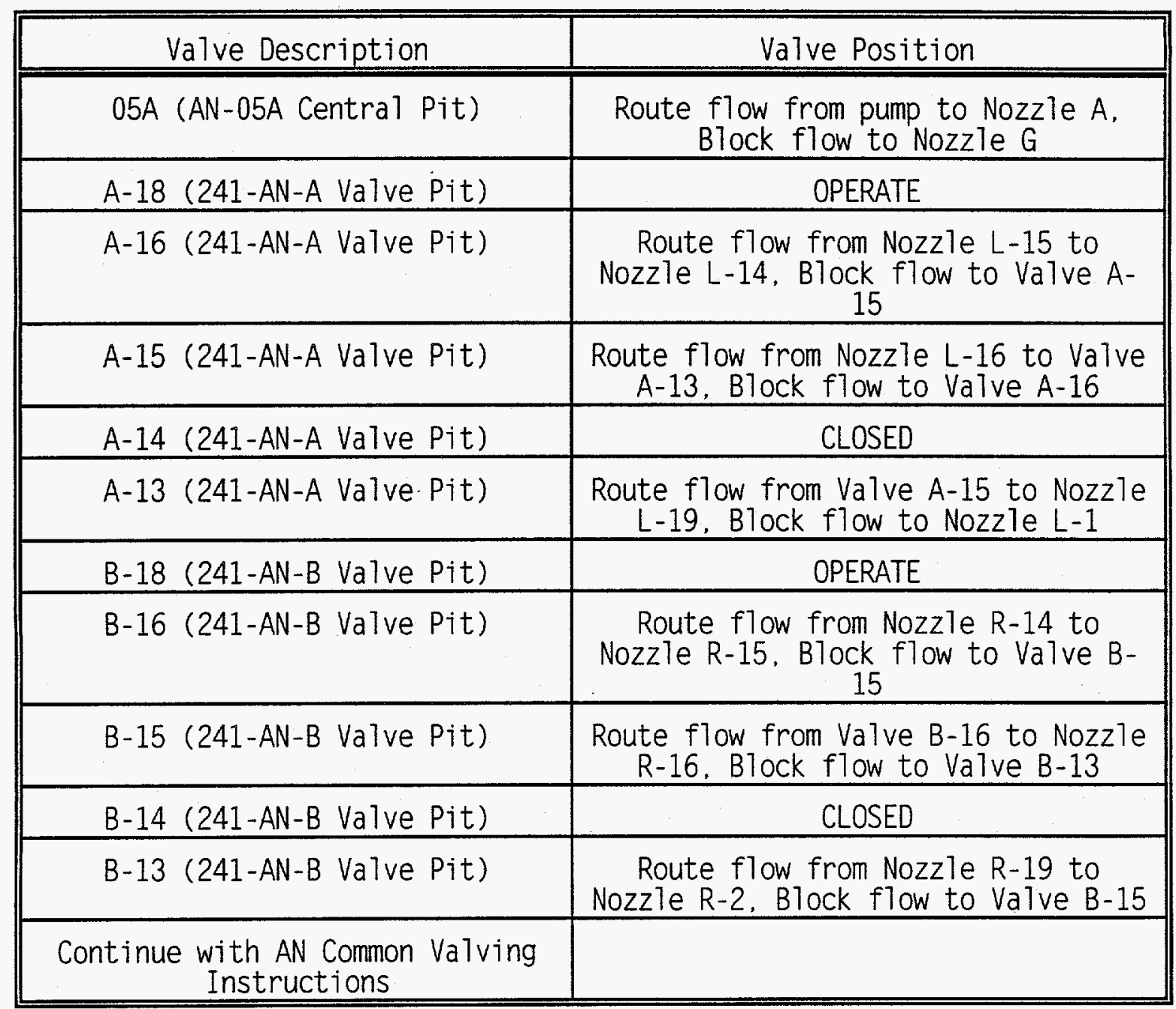


TK-106-AN TO TK-104-AP VALVE POSITION CHECKLIST

\begin{tabular}{|c|c|}
\hline Valve Description & Valve Position \\
\hline 06A (AN-06A Centra1 Pit) & $\begin{array}{c}\text { Route flow from pump to Nozzle A, } \\
\text { Block flow to Nozzle G }\end{array}$ \\
\hline A-18 (241-AN-A valve Pit) & OPERATE \\
\hline A-16 (241-AN-A Valve Pit) & $\begin{array}{l}\text { Route flow from Nozzle } L-14 \text { to Valve } \\
\text { A-15, Block flow to Nozzle } L-15\end{array}$ \\
\hline A-15 (241-AN-A Valve Pit) & $\begin{array}{l}\text { Route flow from Valve A-16 to Valve } \\
\text { A-13, Block flow to Nozzle } L-16\end{array}$ \\
\hline A-14 (241-AN-A Valve Pit) & CLOSED \\
\hline A-13 (241-AN-A valve Pit) & $\begin{array}{l}\text { Route flow from Valve A-15 to Nozzle } \\
L-19 \text {. Block flow to Nozzle } L-1\end{array}$ \\
\hline B-18 (241-AN-B Valve Pit) & OPERATE \\
\hline B-16 (241-AN-B valve Pit) & $\begin{array}{c}\text { Route flow from Nozzle R-14 to } \\
\text { Nozzle R-15, Block flow to Valve B- } \\
15\end{array}$ \\
\hline B-15 (241-AN-B Valve Pit) & $\begin{array}{l}\text { Route flow from Valve } B-16 \text { to Nozzile } \\
\text { R-16, Block flow to Valve B-13 }\end{array}$ \\
\hline B-14 (241-AN-B Valve Pit) & CLOSED \\
\hline B-13 (241-AN-B valve Pit) & $\begin{array}{l}\text { Route flow from Nozzle R-19 to } \\
\text { Nozzle R-2, Block flow to Valve B-15 }\end{array}$ \\
\hline $\begin{array}{l}\text { Continue with AN Common Vaiving } \\
\text { Instructions }\end{array}$ & \\
\hline
\end{tabular}


WHC-SD-WM-AP-031 REV 0

TK-107-AN TO TK-104-AP VALVE POSITION CHECKLIST

\begin{tabular}{|c|c|}
\hline Valve Description & Valve Position \\
\hline 07A (AN-07A Central Pit) & $\begin{array}{c}\text { Route flow from pump to Nozzle A, } \\
\text { Block flow to Nozzle G }\end{array}$ \\
\hline A-18 (241-AN-A vaive Pit) & OPERATE \\
\hline A-16 (241-AN-A valve Pit) & $\begin{array}{c}\text { Route flow from Nozzle L-14 to } \\
\text { Nozzle L-15, Block flow to Valve A- } \\
15\end{array}$ \\
\hline A-15 (241-AN-A valve Pit) & $\begin{array}{l}\text { Route flow from Valve A-16 to Nozzle } \\
L-16 \text {, Block flow to Valve } A-13\end{array}$ \\
\hline A-14 (241-AN-A valve Pit) & CLOSED \\
\hline A-13 (241-AN-A Valve Pit) & $\begin{array}{c}\text { Route flow from Nozzle } L-1 \text { to Nozzle } \\
L-19 \text {. Block flow to Valve A-15 }\end{array}$ \\
\hline B-18 (241-AN-B valve Pit) & OPERATE \\
\hline B-16 (241-AN-B valve Pit) & $\begin{array}{c}\text { Route flow from Nozzle R-14 to } \\
\text { Nozzle R-15. Block flow to Valve B- } \\
15\end{array}$ \\
\hline B-15 (241-AN-B valve Pit) & $\begin{array}{l}\text { Route flow from Valve } B-16 \text { to Nozzle } \\
\text { R-16. Block flow to Valve B-13 }\end{array}$ \\
\hline B-14 (241-AN-B valve Pit) & CLOSED \\
\hline B-13 (241-AN-B valve Pit) & $\begin{array}{l}\text { Route flow from Nozzle R-19 to } \\
\text { Nozzle R-2, Block flow to Valve B-15 }\end{array}$ \\
\hline $\begin{array}{c}\text { Continue with AN Common Val } \\
\text { Instructions }\end{array}$ & \\
\hline
\end{tabular}


AN COMMON VALVING INSTRUCTIONS

CHECKLIST FOR TRANSFERS FROM AN FARM TO TK-104-AP

\begin{tabular}{|c|c|}
\hline Valve Designation & VaTve Position \\
\hline 14A (241-AW-A valve Pit) & OPEN \\
\hline 12A (241-AW-A Valve Pit) & OPEN \\
\hline 13A (241-AW-A Valve Pit) & CLOSED \\
\hline $17 A$ (241-AW-A valve Pit) & OPERATE \\
\hline V-267-1 (AW-02A Pump Pit) & Route flow from Nozzle J to Nozzle $v$ \\
\hline V-267-2 (AW-02A Pump Pit) & CLOSED \\
\hline V-268-1 (AW-02A Pump Pit) & Route flow from Nozzle $H$ to Valve $V-268-2$ \\
\hline V-268-2 (AW-02A Pump Pit) & CLOSED \\
\hline 02A-2 (AW-02A Pump Pit) & OPERATE \\
\hline$V-609-1$ & OPEN \\
\hline$V-609-2$ & OPEN \\
\hline$V-609-3$ & CLOSED \\
\hline$V-610-1$ & CLOSED \\
\hline$V-610-2$ & CLOSED \\
\hline$V-610-3$ & CLOSED \\
\hline$V-611-1$ & $\begin{array}{c}\text { Route flow from valve } V-613-1 \text { To } V-612-1 \text {, } \\
\text { Block flow to valve } V-611-2\end{array}$ \\
\hline$V-611-2$ & CLOSED \\
\hline$V-612-1$ & $\begin{array}{l}\text { Route flow from valve } V-611-1 \text { to } V-614-1 \text {; } \\
\text { Block flow to valve } V-612-2\end{array}$ \\
\hline$V-612-2$ & CLOSED \\
\hline$V-613-1$ & $\begin{array}{l}\text { Route flow from valve } V-609-2 \text { to } V-611-1 \text {, } \\
\text { Block flow to valve } V-613-2\end{array}$ \\
\hline$V-613-2$ & CLOSED \\
\hline$V-614-1$ & OPEN \\
\hline$V-615-1$ & CLOSED \\
\hline$V-616-1$ & $\begin{array}{c}\text { Route flow from Valve } V-616-2 \text { to } V-618-1 \text {, } \\
\text { Block flow to Valve } V-610-2\end{array}$ \\
\hline
\end{tabular}


WHC-SD-WM-AP-031 REV 0

\begin{tabular}{|c|c|}
\hline$V-616-2$ & CLOSED \\
\hline$V-617-1$ & $\begin{array}{r}\text { Route flow from Valve V-617-2 to V-615-1, } \\
\text { Block flow to Valve V-618-1 }\end{array}$ \\
\hline$V-617-2$ & CLOSED \\
\hline$V-618-1$ & Block flow to Valve V-616-1 \\
\hline$V-618-2$ & CLOSED \\
\hline$V-F L-1$ & CLOSED \\
\hline$V-F L-2$ & CLOSED \\
\hline$V-D R-1$ & CLOSED \\
\hline 04A (AP-04A Central Pit) & Route flow from Nozzle A to Nozzle E, \\
Block flow to pump
\end{tabular}


WHC-SD-WM-AP-031 REV 0

Leak Detection Equipment

10I-AN

Type

LIT-101-AN

Manual Tape

LDE-01A-1 SYS

LDE-VP-AN B S-YS

LDE-24IAN-SN260S-YS

LDE-102-18

LDE-SN-600

LDE-241-AX-A

PS-SN-201

LDE-241A-A-VP

LDE-241AW-SN220

LDE-VP-AW-A

LDE-241AW-SN267

LDE-2A-1

LDE-609

LDE-VP-1

LDE-04A-1

Manual Tape

LIT-104-1

102-AN

LIT-102-AN

Manual Tape

LDE-02A-1 SYS

LDE-VP-AN B S-YS

LDE-241AN-SN260S-YS

LDE $-102-18$

LDE-SN-600

LDE-241-AX-A

PS-SN-201

LDE-241A-A-VP

LDE-241AW-SN220

LDE-VP-AW-A

LDE-241AW-SN267

LDE-2A-1

LDE-609

LDE-VP-1

LDE-04A-1

Manua 7 Tape

LIT-104-1
Location

TK-101-AN

TK-101-AN

AN-01A

241-AN-B

$\mathrm{SN}-260$

$A Z-02 B$

SN -600

241-AX-A

SN-201/214

241-A-A

$\mathrm{SN}-220$

241-AW-A

SN-267 (AW)

AW-02A

SN-609

241-AP VP

$A P-04 A$

TK-104-AP

TK-104-AP

TK-102-AN

TK-102-AN

AN-02A

24I-AN-B

$S N-260$

$A Z-02 B$

$\mathrm{SN}-600$

$241-A X-A$

SN-201/214

241-A-A

$\mathrm{SN}-220$

241-AW-A

SN-267 (AW)

AW-02A

$\mathrm{SN}-609$

241-AP VP

AP-04A

TK-104-AP

TK-104-AP
CBRS Description

AN011-2

TK-101-AN Manual Tape

AN012-1

AN233-1

AN027-1

AZ055-1

AZ198-1

AX177-1

AY188/AY191-1

2R072-1

AW068-1

AW004-1

AW069-1

AW086-I

AP151-1

AP801-1

AP165-1

TK-104-AP

AP105-2

AN143-2

TK-102-AN Manua1 Tape

AN144-1

AN233-1

AN027-1

AZ055-1

AZ198-1

AX177-1

AY188/AY191-1

2R072-1

AW068-1

AW004-1

AW069-1

AW086-1

AP151-1

AP801-1

AP165-1

TK-104-AP

AP105-2 
WHC-SD-WM-AP-031 REV 0

103-AN

\section{Type}

LIT-103-AN

Manual Tape

LDE-03A-1 SYS

LDE-VP-AN B S-YS

LDE-241AN-SN260S-YS

LDE-102-18

LDE-SN-600

LDE-241-AX-A

PS-SN-201

LDE-241A-A-VP

LDE-241AW-SN220

LDE-VP-AW-A

LDE-241AW-SN267

LDE-2A-1

LDE-609

LDE-VP-1

LDE-04A-1

Manua 7 Tape

LIT-104-1

104-AN

LIT-104-AN
Manua] Tape
LDE-04A-1 SYS
LDE-VP-AN A S-YS
LDE-241AN-SN2-68
LDE-VP-AN B S-YS
LDE-241AN-SN260S-YS
LDE-102-18
LDE-SN-600
LDE-241-AX-A
PS-SN-201
LDE-241A-A-VP
LDE-241AW-SN220
LDE-VP-AW-A
LDE-241AW-SN267
LDE-2A-1
LDE-609
LDE-VP-1
LDE-04A-1
ManUa T Tape
LIT-104-1

\section{Location}

TK-103-AN

TK-103-AN

AN-03A

$241-A N-B$

$\mathrm{SN}-260$

$\mathrm{AZ}-02 \mathrm{~B}$

$\mathrm{SN}-600$

241-AX-A

SN-201/214

241-A-A

$\mathrm{SN}-220$

241-AW-A

SN-267 (AW)

AW- 02 A

SN-609

241-AP VP

AP-04A

TK-104-AP

TK-104-AP

TK-104-AN

TK-104-AN

AN-04A

241-AN-A

SN-268 (AN)

241-AN-B

$\mathrm{SN}-260$

$A Z-02 B$

$S N-600$

241-AX-A

SN-201/214

241-A-A

SN-220

241-AW-A

SN-267 (AW)

AW- $02 A$

SN-609

241-AP VP

AP-04A

TK-104-AP

TK-104-AP
CBRS Description

AN165-2

TK-103-AN Manual Tape

AN166-1

AN233-1

ANO27-1

AZ055-1

AZ198-1

AX177-1

AY188/AY191-1

2R072-1

AW068-1

AW004-1

AW069-1

AW086-1

AP151-1

AP801-1

AP165-1

TK-104-AP

AP105-2

AN065-2

TK-104-AN Manual Tape

AN066-1

ANO20-1

AN028-1

AN233-1

AN027-1

AZ055-1

AZ198-1

AX177-1

AY188/AY191-1

2R072-1

AW068-1

AW004-1

AW069-1

AW086-1

AP151-1

AP801-1

AP165-1

TK-104-AP

AP105-2 
WHC-SD-WM-AP-031 REV 0

105-AN

Type

LIT-105-AN

Manual Tape

LDE-05A-I SYS

LDE-VP-AN A S-YS

LDE-241AN-SN2-68

LDE-VP-AN B S-YS

LDE-241AN-SN260S-YS

LDE-102-18

LDE-SN-600

LDE-241-AX-A

PS-SN-201

LDE-241A-A-VP

LDE-241AW-SN220

LDE-VP-AW-A

LDE-241AW-SN267

LDE-2A-1

LDE-609

LDE-VP-1

LDE-04A-1

Manual Tape

LIT-104-1

\section{6-AN}

LIT-106-AN
Manual Tape
LDE-06A-1 SYS
LDE-VP-AN A S-YS
LDE-241AN-SN2-68
LDE-VP-AN B S-YS
LDE-241AN-SN260S-YS
LDE-102-18
LDE-SN-600
LDE-241-AX-A
PS-SN-201
LDE-241A-A-VP
LDE-241AW-SN220
LDE-VP-AW-A
LDE-241AW-SN267
LDE-2A-1
LDE-609
LDE-VP-1
LDE-04A-1
ManuaT Tape
LIT-104-1

Location

TK-105-AN

TK-105-AN

AN-05A

241-AN-A

SN-268 (AN)

241-AN-B

$\mathrm{SN}-260$

AZ- $02 B$

$\mathrm{SN}-600$

241-AX-A

SN-201/214

241-A-A

$\mathrm{SN}-220$

241-AW-A

SN-267 (AW)

AW- $02 A$

SN-609

241-AP VP

AP-04A

TK-104-AP

TK-104-AP

TK-106-AN

TK-106-AN

AN-06A

241-AN-A

SN-268 (AN)

241-AN-B

$\mathrm{SN}-260$

$A Z-02 B$

$\mathrm{SN}-600$

241-AX-A

SN-201/214

241-A-A

$S N-220$

241-AW-A

SN-267 (AW)

AW-02A

$\mathrm{SN}-609$

241-AP VP

AP-04A

TK-104-AP

TK-104-AP

\section{CBRS Description}

AN179-2

TK-105-AN Manual Tape

AN182-1

AN020-1

AN028-1

AN233-1

AN027-1

AZ055-1

AZ198-1

AX177-1

AY188/AY191-1

2R072-1

AW068-1

AW004-1

Aw069-1

AW086-1

AP151-1

AP801-1

AP165-1

TK-104-AP

AP105-2

AN200-2

TK-106-AN Manual Tape

AN204-1

AN020-1

AN028-1

AN233-1

AN027-1

AZ055-1

AZ198-1

AX177-1

AY188/AY191-1

2R072-1

AW068-1

AW004-1

AW069-1

AW086-1

AP151-1

AP801-1

AP165-1

TK-104-AP

AP105-2 


\section{$107 \cdot$ AN}

Type
LIT-107-AN
Manual Tape
LDE-07A-A SYS
LDE-VP-AN A S-YS
LDE-241AN-SN2-68
LDE-VP-AN B S-YS
LDE-241AN-SN260S-YS
LDE-102-18
LDE-SN-600
LDE-241-AX-A
PS-SN-201
LDE-241A-A-VP
LDE-241AW-SN220
LDE-VP-AW-A
LDE-241AW-SN267
LDE-2A-1
LDE-609
LDE-VP-1
LDE-04A-1
Manua1 Tape
LIT-104-1

Location

TK-107-AN

TK-107-AN

AN-07A

241-AN-A

SN-268 (AN)

241-AN-B

SN-260

$\mathrm{AZ}-02 \mathrm{~B}$

$\mathrm{SN}-600$

241-AX-A

SN-201/214

$241-A-A$

$\mathrm{SN}-220$

241-AW-A

SN-267 (AW)

AW-02A

SN-609

241-AP VP

AP-04A

TK-104-AP

TK-104-AP

\section{CBRS Description}

AN219-2

TK-107-AN Manual Tape

AN220-1

ANO20-1

AN028-1

AN233-1

AN027-1

AZ055-1

AZ198-1

AX177-1

AY188/AY191-1

2R072-1

AW068-1

AW004-1

AW069-1

AW086-1

AP151-1

AP801-1

AP165-1

TK-104-AP

AP105-2 
WHC-SD-WM-AP-031 REV 0

HydrauTic Diagrams, AN Farm 


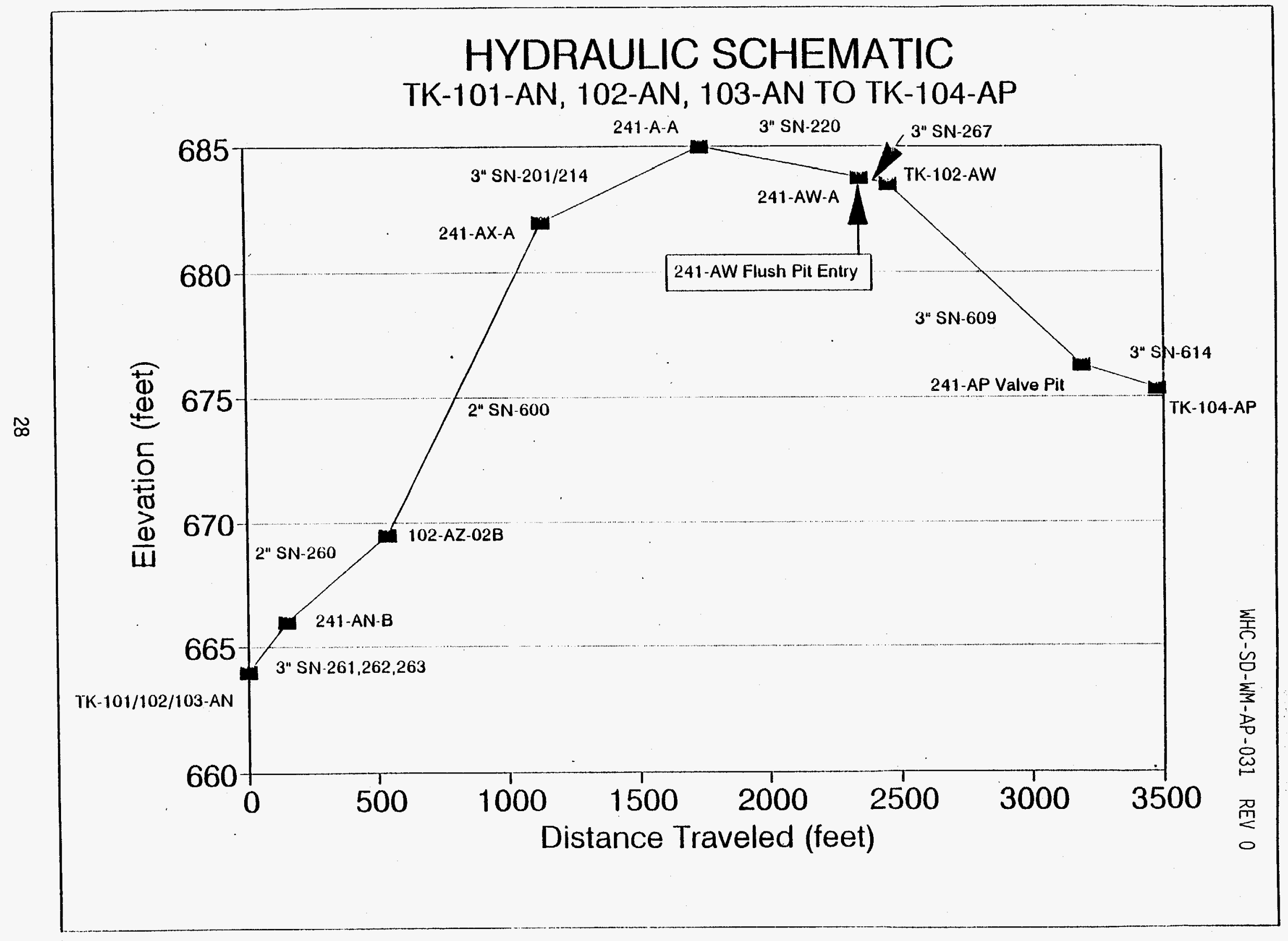




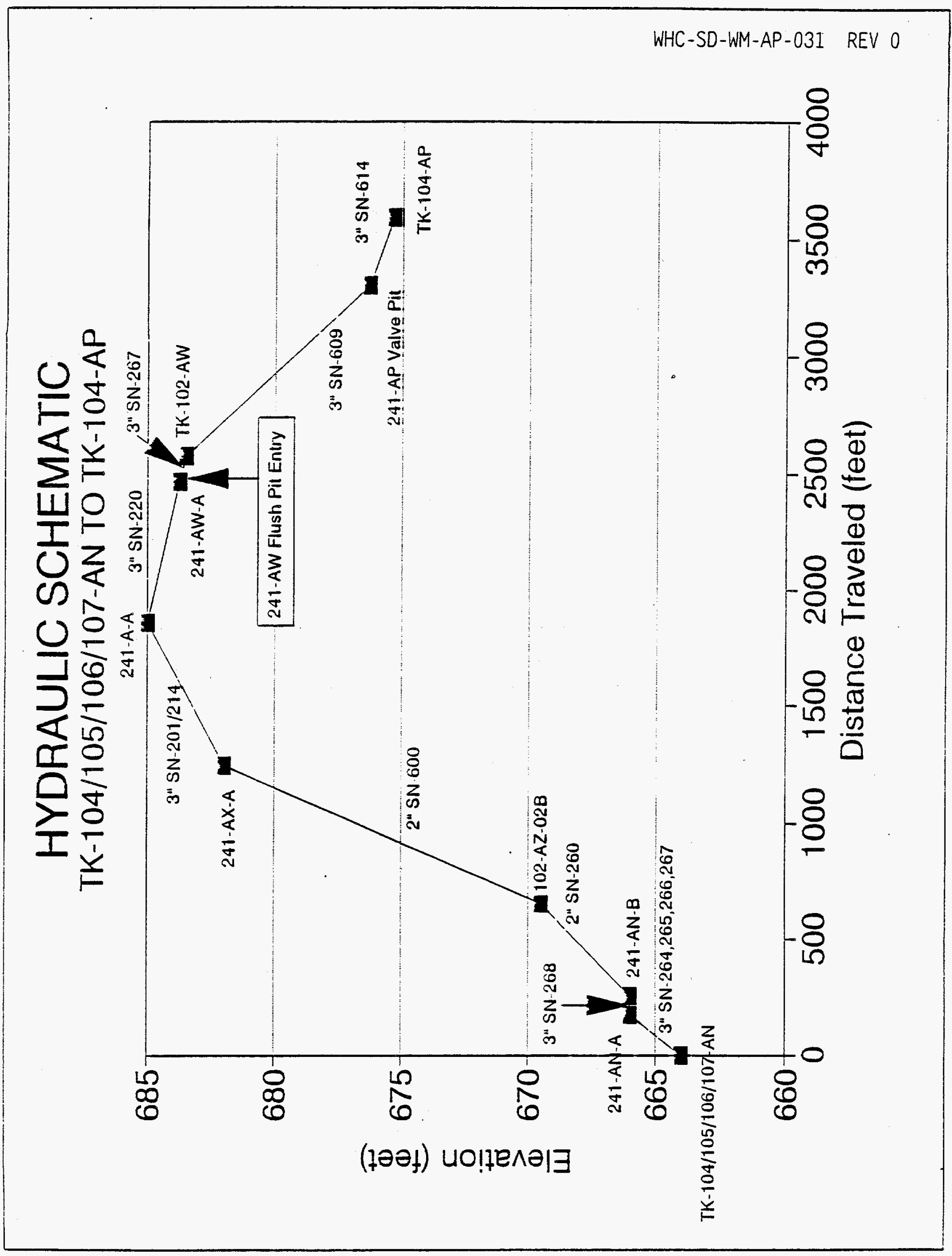


WHC-SD-WM-AP-031 REV 0

APPENDIX B: TRANSFER DATA, AW FARM

\section{Transfer Routes}

\section{TK-101-AW}

Route: Transfer Pump (01A Pit) to SN-261

SN-261 to 241-AW-A Valve Pit

SN-267 from 241-AW-A Valve Pit to TK-102-AW

SN-609 from TK-102-AW to 241-AP Valve Pit

SN-614 from 241-AP Valve Pit to TK-104-AP

Jumpers: Nozzle L-16 to Nozzle L-1 in AW-A Pit

Nozzle $\mathrm{J}$ to Nozzle $V$ in TK-102-AW

Nozzle 14 to Nozzle 20 in 241-AP Valve Pit

\section{TK-102-AW}

Route: Transfer Pump (02A Pit) to SN-609

SN-609 to 241-AP Valve Pit

SN-614 from 241-AP Valve Pit to TK-104-AP

Jumpers: Nozzle 14 to Nozzle 20 in 241-AP Valve Pit

TK-103-AW

Route: Transfer Pump (03A Pit) to SN-263

SN-263 to 241-AW-A Valve Pit

SN-267 from 241-AW-A Valve Pit to TK-102-AW

SN-609 from TK-102-AW to 241-AP Valve Pit

SN-614 from 241-AP Valve Pit to TK-104-AP

Jumpers: Nozzle L-14 to Nozzle L-1 in AW-A Pit Nozzle $\mathrm{J}$ to Nozzle $\mathrm{V}$ in TK-102-AW

Nozzle 14 to Nozzle 20 in 241-AP Valve Pit

\section{TK-104-AW}

Route: Transfer Pump (04A Pit) to SN-264

SN-264 to 241-AW-B Valve Pit

SN-268 from 241-AW-B Valve Pit to TK-102-AW

SN-610 from TK-102-AW to 241-AP Valve Pit

SN-614 from 241-AP Valve Pit to TK-104-AP

Jumpers: Nozzle R-14 to Nozzle R-1 in AW-B Pit Nozzle $\mathrm{H}$ to Nozzle $U$ in TK-102-AW

Nozzle 13 to Nozzle 20 in 241-AP Valve Pit 
WHC-SD-WM-AP-031 REV 0

TK· 105-AW

Route: Transfer Pump (05A Pit) to SN-265

SN-265 to 241-AW-A Valve Pit

SN-267 from 241-AW-A Valve Pit to TK-102-AW

SN-609 from TK-102-AW to 241-AP Valve Pit

SN-614 from 241-AP Valve Pit to TK-104-AP

Jumpers: Nozzle L-15 to Nozzle L-1 in AW-A Pit Nozzle $J$ to Nozzle $V$ in TK-102-AW

Nozzle 14 to Nozzle 20 in 241-AP Valve Pit

\section{TK-106-AW}

Route: Transfer Pump (06A Pit) to SN-266

SN-266 to 241-AW-B Valve Pit

SN-268 from 241-AW-B Valve Pit to TK-102-AW

SN-610 from TK-102-AW to 241-AP Valve Pit

SN-614 from 241-AP Valve Pit to TK-104-AP

Jumpers: Nozzle R-15 to Nozzle R-1 in AW-B Pit Nozzle $\mathrm{H}$ to Nozzle $\mathrm{U}$ in TK-102-AW

Nozzle 13 to Nozzle 20 in 241-AP Valve Pit 


\section{Valve Checklists}

\section{TK-101-AW TO TK-104-AP VALVE POSITION CHECKLIST}

\begin{tabular}{|c|c|}
\hline Valve Description & Valve Position \\
\hline \hline 01A (AW-01A Central Pit) & $\begin{array}{c}\text { Route flow from pump to Nozzle A, } \\
\text { Block Flow to Nozzle G }\end{array}$ \\
\hline 12A (241-AW-A Valve Pit) & OPEN \\
\hline 13A (241-AW-A Valve Pit) & CLOSED \\
\hline 14A (241-AW-A Valve Pit) & OPEN \\
\hline 17A (241-AW-A Valve Pit) & OPERATE \\
\hline V267-1 (102-AW-02A) & Route flow from Nozzle J to Nozzle V \\
\hline 02A-2 (102-AW-02A Pit) & OPERATE \\
\hline V267-2 (102-AW-02A) & \\
\hline $\begin{array}{c}\text { Continue with AW Common Valving } \\
\text { Instructions }\end{array}$ & \\
\hline & \\
\hline
\end{tabular}


WHC-SD-WM-AP-031 REV 0

TK-102-AW TO TK-104-AP VALVE POSITION CHECKLIST

\begin{tabular}{|c|c|}
\hline Valve Description & Valve Position \\
\hline \hline Flex Jumper & Insta11 between pump and Nozzle V \\
\hline V-267-1 (102-AW-02A Pit) & Block flow to Nozzle V \\
\hline V-267-2 (102-AW-02A Pit) & CLOSED \\
\hline 02A-2 (AW-02A Pump Pit) & OPERATE \\
\hline & \\
\hline & \\
\hline
\end{tabular}


WHC-SD-WM-AP-031 REV 0

TK-103-AW TO TK-104-AP VALVE POSITION CHECKLIST

\begin{tabular}{|c|c|}
\hline Valve Description & Valve Position \\
\hline \hline 03A (AW-03A Central Pit) & $\begin{array}{c}\text { Route flow from pump to Nozzle A, } \\
\text { Block flow to Nozzle G }\end{array}$ \\
\hline 12A (241-AW-A Valve Pit) & OPEN \\
\hline 13A (241-AW-A Valve Pit) & CLOSED \\
\hline 14A (241-AW-A Valve Pit) & OPEN \\
\hline 17A (241-AW-A Valve Pit) & OPERATE \\
\hline 02A-2 (102-AW-02A Pit) & OPERATE \\
\hline V267-1 (102-AW-02A) & Route flow from Nozzle J to Nozzle V \\
\hline V267-2 (102-AW-02A) & \\
\hline Continue with AW Common Valving & \\
\hline Instructions & \\
\hline & \\
\hline
\end{tabular}


WHC-SD-WM-AP-031 REV 0

TK-104-AW TO TK-104-AP VALVE POSITION CHECKLIST

\begin{tabular}{|c|c|}
\hline Valve Description & Valve Position \\
\hline 04A (AW-04A Centra1 Pit) & $\begin{array}{c}\text { Route flow from pump to Nozzle A, } \\
\text { Block flow to Nozzle G }\end{array}$ \\
\hline 12B (241-AW-B Valve Pit) & OPEN \\
\hline 13B (241-AW-B Valve Pit) & CLOSED \\
\hline 14B (241-AW-B Valve Pit) & OPEN \\
\hline 17B (241-AW-B Valve Pit) & OPERATE \\
\hline V268-1 (102-AW-02A Valve Pit) & Route flow from Nozzle $\mathrm{H}$ to Nozzle U \\
\hline V268-2 (102-AW-02A Valve Pit) & CLOSED \\
\hline 02A-2 (102-AW-02A Pit) & OPERATE \\
\hline V-609-1 (241-AP Valve Pit) & CLOSED \\
\hline V-609-2 (241-AP Valve Pit) & OPEN \\
\hline V-609-3 (241-AP VaTve Pit) & OPEN \\
\hline V-610-1 (241-AP Valve Pit) & OPEN \\
\hline V-610-2 (241-AP Valve Pit) & CLOSED \\
\hline V-610-3 (241-AP Valve Pit) & OPEN \\
\hline V-611-1 (241-AP Valve Pit) & $\begin{array}{l}\text { Route flow from Valve } V-613-1 \text { To } V \text { - } \\
612-1 \text {. Block flow to Valve } V-611-2 \\
\end{array}$ \\
\hline V-611-2 (241-AP Valve Pit) & CLOSED \\
\hline V-612-1 (241-AP Valve Pit) & $\begin{array}{l}\text { Route flow from Valve } V-611-1 \text { to } V \text { - } \\
614-1 \text {, Block flow to Valve } V-612-2 \\
\end{array}$ \\
\hline V-612-2 (241-AP Valve Pit) & CLOSED \\
\hline V-613-1 (241-AP Valve Pit) & $\begin{array}{l}\text { Route flow from Valve } V-609-2 \text { to } V \text { - } \\
611-1 \text {, Block flow to Valve } V-613-2 \\
\end{array}$ \\
\hline V-613-2 (241-AP Valve Pit) & CLOSED \\
\hline V-614-1 (241-AP Valve Pit) & OPEN \\
\hline V-615-1 (241-AP Valve Pit) & CLOSED \\
\hline V-616-1 (241-AP Valve Pit) & $\begin{array}{l}\text { Route flow from Valve } V-616-2 \text { to } V \text { - } \\
618-1 \text {, Block flow to VaTve } V-610-2 \\
\end{array}$ \\
\hline V-616-2 (241-AP Valve Pit) & CLOSED \\
\hline
\end{tabular}


WHC-SD-WM-AP-031 REV 0

\begin{tabular}{||c|c||}
\hline V-617-1 (241-AP Valve Pit) & $\begin{array}{c}\text { Route flow from Valve V-617-2 to V- } \\
615-1, \text { Block flow to Valve V-618-1 }\end{array}$ \\
\hline V-617-2 (241-AP Valve Pit) & CLOSED \\
\hline V-618-1 (241-AP Valve Pit) & $\begin{array}{c}\text { Route flow from Valve V-616-1 to V- } \\
617-1, \text { Block flow to Valve V-618-2 }\end{array}$ \\
\hline V-618-2 (241-AP Valve Pit) & CLOSED \\
\hline V-FL-1 (241-AP Valve Pit) & CLOSED \\
\hline V-FL-2 (241-AP Vaive Pit) & CLOSED \\
\hline V-DR-1 (241-AP Valve Pit) & CLOSED \\
\hline O4A (AP-04A Central Pit) & Route flow from Nozzle A to Nozzle \\
\hline
\end{tabular}


WHC-SD-WM-AP-031 REV 0

\section{TK-105-AW TO TK-104-AP VALVE POSITION CHECKLIST}

\begin{tabular}{|c|c|}
\hline Valve Description & Valve Position \\
\hline \hline 05A (AW-05A Central Pit) & $\begin{array}{c}\text { Route flow from pump to Nozzle A, } \\
\text { Block flow to Nozzle G }\end{array}$ \\
\hline 12A (241-AW-A Valve Pit) & OPEN \\
\hline 13A (241-AW-A Valve Pit) & CLOSED \\
\hline 14A (241-AW-A Valve Pit) & OPEN \\
\hline 17A (241-AW-A Valve Pit) & OPERATE \\
\hline 02A-2 (102-AW-02A Pit) & OPERATE \\
\hline V267-1 (102-AW-02A) & Route flow from Nozzle J to Nozzle V \\
\hline V267-2 (102-AW-02A) & CLOSED \\
\hline $\begin{array}{c}\text { Continue with AW Common Valving } \\
\text { Instructions }\end{array}$ & \\
\hline & \\
\hline
\end{tabular}


TK-106-AW TO TK-104-AP VALVE POSITION CHECKLIST

\begin{tabular}{|c|c|}
\hline Valve Description & Valve Position \\
\hline 06A (AW-06A Central Pit) & $\begin{array}{c}\text { Route flow from pump to Nozzle A, } \\
\text { Block flow to Nozzle G }\end{array}$ \\
\hline 12B (241-AW-B Valve Pit) & OPEN \\
\hline 13B (241-AW-B Valve Pit) & CLOSED \\
\hline $14 B$ (241-AW-B Valve Pit) & OPEN \\
\hline 17B (241-AW-B Valve Pit) & OPERATE \\
\hline 02A-2 (102-AW-02A Pit) & OPERATE \\
\hline V268-1 (102-AW-02A Valve Pit) & Route flow from Nozzle $\mathrm{H}$ to Nozzle U \\
\hline V268-2 (102-AW-02A Valve Pit) & CLOSED \\
\hline V-609-1 (241-AP Valve Pit) & CLOSED \\
\hline V-609-2 (241-AP Valve Pit) & OPEN \\
\hline V-609-3 (241-AP Valve Pit) & OPEN \\
\hline V-610-1 (241-AP Valve Pit) & OPEN \\
\hline V-610-2 (241-AP Valve Pit) & CLOSED \\
\hline V-610-3 (241-AP Valve Pit) & OPEN \\
\hline V-611-1 (241-AP Valve Pit) & $\begin{array}{l}\text { Route flow from Valve } V-613-1 \text { To } V- \\
612-1 \text {, Block flow to Valve V-611-2 }\end{array}$ \\
\hline V-611-2 (241-AP Valve Pit) & CLOSED \\
\hline V-612-1 (241-AP Valve Pit) & $\begin{array}{l}\text { Route flow from Valve } V-611-1 \text { to } V- \\
614-1 \text {, Block flow to Valve } V-612-2\end{array}$ \\
\hline V-612-2 (241-AP VaTve Pit) & CLOSED \\
\hline V-613-1 (241-AP Valve Pit) & $\begin{array}{l}\text { Route flow from Valve } V-609-2 \text { to } V \text { - } \\
611-1 \text {, Block flow to Valve } V-613-2\end{array}$ \\
\hline V-613-2 (241-AP Valve Pit) & CLOSED \\
\hline V-614-1 (241-AP Valve Pit) & OPEN \\
\hline V-615-1 (241-AP Valve Pit) & CLOSED \\
\hline V-616-1 (241-AP Valve Pit) & $\begin{array}{l}\text { Route flow from Valve } V-616-2 \text { to } V- \\
618-1 \text {. Block flow to Valve } V-610-2\end{array}$ \\
\hline V-616-2 (241-AP Valve Pit) & CLOSED \\
\hline
\end{tabular}


WHC-SD-WM-AP-031 REV 0

\begin{tabular}{|c|c|}
\hline V-617-1 (241-AP Valve Pit) & $\begin{array}{l}\text { Route flow from Valve } V-617-2 \text { to } V- \\
615-1 \text {. Block flow to Valve } V-618-1 \\
\end{array}$ \\
\hline V-617-2 (241-AP Valve Pit) & CLOSED \\
\hline V-618-1 (241-AP Valve Pit) & $\begin{array}{l}\text { Route flow from Valve } V-616-1 \text { to } V- \\
617-1 \text {, Block flow to Valve } V-618-2\end{array}$ \\
\hline V-618-2 (241-AP Valve Pit) & CLOSED \\
\hline V-FL-1 (241-AP Valve Pit) & CLOSED \\
\hline V-FL-2 (241-AP Valve Pit) & CLOSED \\
\hline V-DR-1 (241-AP Valve Pit) & CLOSED \\
\hline 04A (AP-04A Centra1 Pit) & $\begin{array}{c}\text { Route flow from Nozzle A to Nozzle } \\
\text { E, Block flow to pump }\end{array}$ \\
\hline
\end{tabular}


AW COMMON VALVING INSTRUCTIONS

CHECKLIST FOR TRANSFERS FROM AW-101, -102, -103, -105 TO TK-104-AP

\begin{tabular}{|c|c|}
\hline Valve Designation & Valve Position \\
\hline V-609-1 (241-AP Valve Pit) & OPEN \\
\hline V-609-2 (241-AP Valve Pit) & OPEN \\
\hline V-609-3 (241-AP Valve Pit) & CLOSED \\
\hline V-610-1 (241-AP Valve Pit) & CLOSED \\
\hline V-610-2 (241-AP Valve Pit) & CLOSED \\
\hline V-610-3 (241-AP Valve Pit) & CLOSED \\
\hline V-611-1 (241-AP Valve Pit) & $\begin{array}{l}\text { Route flow from Valve } V-613-1 \text { To } V-612-1 \text {, Block } \\
\text { flow to Valve } V-611-2\end{array}$ \\
\hline V-611-2 (241-AP Valve Pit) & CLOSED \\
\hline V-612-1 (241-AP Valve Pit) & $\begin{array}{c}\text { Route flow from Valve } V-611-1 \text { to } V-614-1 \text {, Block } \\
\text { flow to valve } V-612-2\end{array}$ \\
\hline V-612-2 (241-AP Valve Pit) & CLOSED \\
\hline V-613-1 (241-AP Valve Pit) & $\begin{array}{c}\text { Route flow from Valve } V-609-2 \text { to } V-611-1 \text {, Block } \\
\text { flow to valve } V-613-2\end{array}$ \\
\hline V-613-2 (241-AP Valve Pit) & CLOSED \\
\hline V-614-1 (241-AP Valve Pit) & OPEN \\
\hline V-615-I (241-AP Valve Pit) & CLOSED \\
\hline V-616-1 (241-AP Valve Pit) & $\begin{array}{c}\text { Route flow from Valve } V-616-2 \text { to } V-618-1 \text {, Block } \\
\text { flow to Valve } V-610-2\end{array}$ \\
\hline V-616-2 (241-AP Valve Pit) & CLOSED \\
\hline V-617-1 (241-AP Vaive Pit) & $\begin{array}{c}\text { Route flow from Valve } V-617-2 \text { to } V-615-1 \text {, Block } \\
\text { flow to Valve } V-618-1\end{array}$ \\
\hline V-617-2 (241-AP Valve Pit) & CLOSED \\
\hline V-618-1 (241-AP Valve Pit) & Block flow to valve $V-616-1$ \\
\hline V-618-2 (241-AP Valve Pit) & CLOSED \\
\hline V-FL-1 (241-AP Valve Pit) & CLOSED \\
\hline V-FL-2 (241-AP Valve Pit) & CLOSED \\
\hline V-DR-1 (241-AP valve Pit) & CLOSED \\
\hline 04A (AP-04A Central Pit) & $\begin{array}{c}\text { Route flow from Nozzle A to Nozzle E, Block flow } \\
\text { to pump }\end{array}$ \\
\hline
\end{tabular}


Leak Detection Equipment

101-AW

Type

LIT-101-1

Manual Tape

LDE-1A-1

LDE-VP-AW-A

LDE-241AW-SN267

LDE $-2 A-1$

LDE-609

LDE-VP-1

LDE-04A-1

Manua 7 Tape

LIT-104-1

102-AW

LIT-102-1

Manual Tape

LDE-2A-1

LDE-609

LDE-VP-1

LDE-04A-1

Manual Tape

LIT-104-1

103-AW

LIT-103-1

Manual Tape

LDE-3A-1

LDE-VP-AW-A

LDE-241AW-SN267

LDE $-2 A-1$

LDE-609

LDE-VP-1

LDE-04A-1

Manual Tape

LIT-104-1

\section{Location}

TK-101-AW

TK-101-AW

AW-01A

241-AW-A

SN-267 (AW)

AW- 02 A

$\mathrm{SN}-609$

241-AP VP

AP-04A

TK-104-AP

TK-104-AP

TK-102-AW

TK-102-AW

AW-02A

$\mathrm{SN}-609$

241-AP VP

AP-04A

TK-104-AP

TK-104-AP

TK-103-AW

TK-103-AW

AW-03A

241-AW-A

SN-267 (AW)

AW-02A

$S N-609$

241-AP VP

AP- $04 \mathrm{~A}$

TK-104-AP

TK-104-AP
CBRS Description

AW062-2

TK-101-AW Manual Tape

AW063-1

AW004-1

AW069-1

AW086-1

AP151-1

AP801-1

AP165-1

TK-104-AP

AP105-2

AW088-2

TK-102-AW Manual Tape

AW086-1

AP151-1

AP801-1

AP165-1

TK-104-AP

AP105-2

AW094-2

TK-103-AW Manual Tape

AW096-1

AW004-1

AW069-1

AW086-1

AP151-1

AP801-1

AP165-1

TK-104-AP

AP105-2 
104-AW

Type

LIT-104-1

Manua 7 Tape

LDE-4A-1

LDE-VP-AW-B

LDE-241AW-SN268

LDE-2A-1

LDE-609

LDE-VP-1

LDE-04A-1

Manual Tape

LIT-104-1

105-AW

LIT

Manual Tape

LDE

LDE-VP-AW-A

LDE-241AW-SN267

LDE-2A-1

LDE -609

LDE-VP-1

LDE-04A-1

Manua 7 Tape

LIT-104-1

\section{6-AW}

LIT
Manua1 Tape
LDE
LDE-VP-AW-B
LDE-241AW-SN268
LDE-2A-1
LDE-609
LDE-VP-1
LDE-04A-1
Manua 1 Tape
LIT-104-1

\section{Location}

TK-104-AW

TK-104-AW

AW-04A

$241-A W-B$

$\mathrm{SN}-268$ (AW)

AW-02A

SN -609

241-AP VP

AP-04A

TK-104-AP

TK-104-AP

TK-105-AW

TK-105-AW

AW-05A

241-AW-A

SN-267 (AW)

AW-02A

SN-609

241-AP VP

AP-04A

TK-104-AP

TK-104-AP

TK-106-AW

TK-106-AW

AW-06A

241-AW-B

$S N-268$ (AW)

AW-02A

SN-609

241-AP VP

AP-04A

TK-104-AP

TK-104-AP

\section{CBRS Description}

AW095-2

TK-104-AW Manual Tape

AW097-1

AW005-1

AW 070-1

AW086-1

AP151-1

AP801-1

AP165-1

TK-104-AP

AP105-2

AW117-2

TK-105-AW Manual Tape

AW119-1

AW004-1

AW069-1

AW086-1

AP151-1

AP801-1

AP165-1

TK-104-AP

AP105-2

AW118-2

TK-106-AW Manual Tape

AW120-1

AW005-1

AW070-1

AW086-1

AP151-1

AP801-1

AP165-1

TK-104-AP

AP105-2 
WHC-SD-WM-AP-031 REV 0

Hydraulic Diagrams, AW Farm 


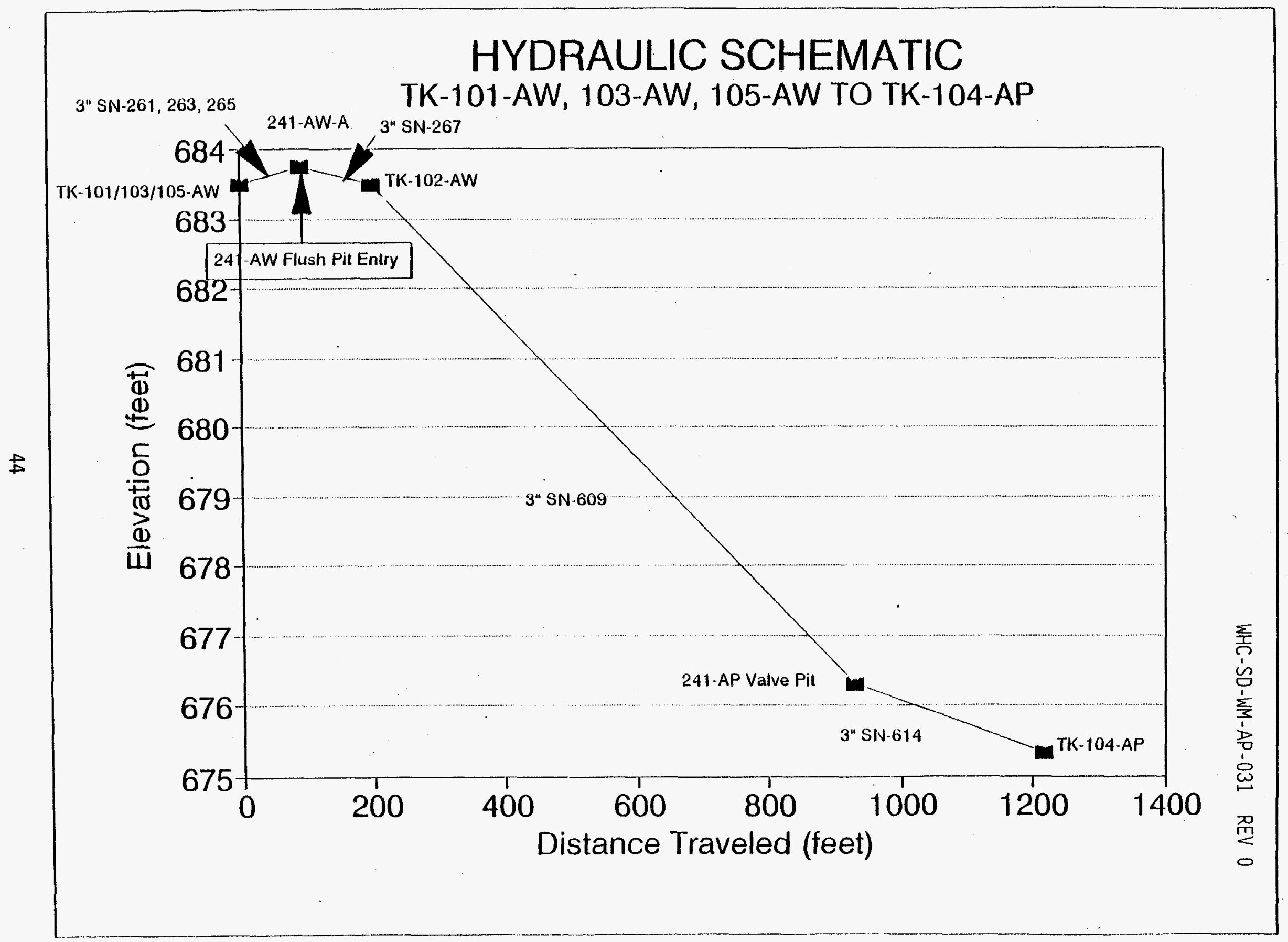




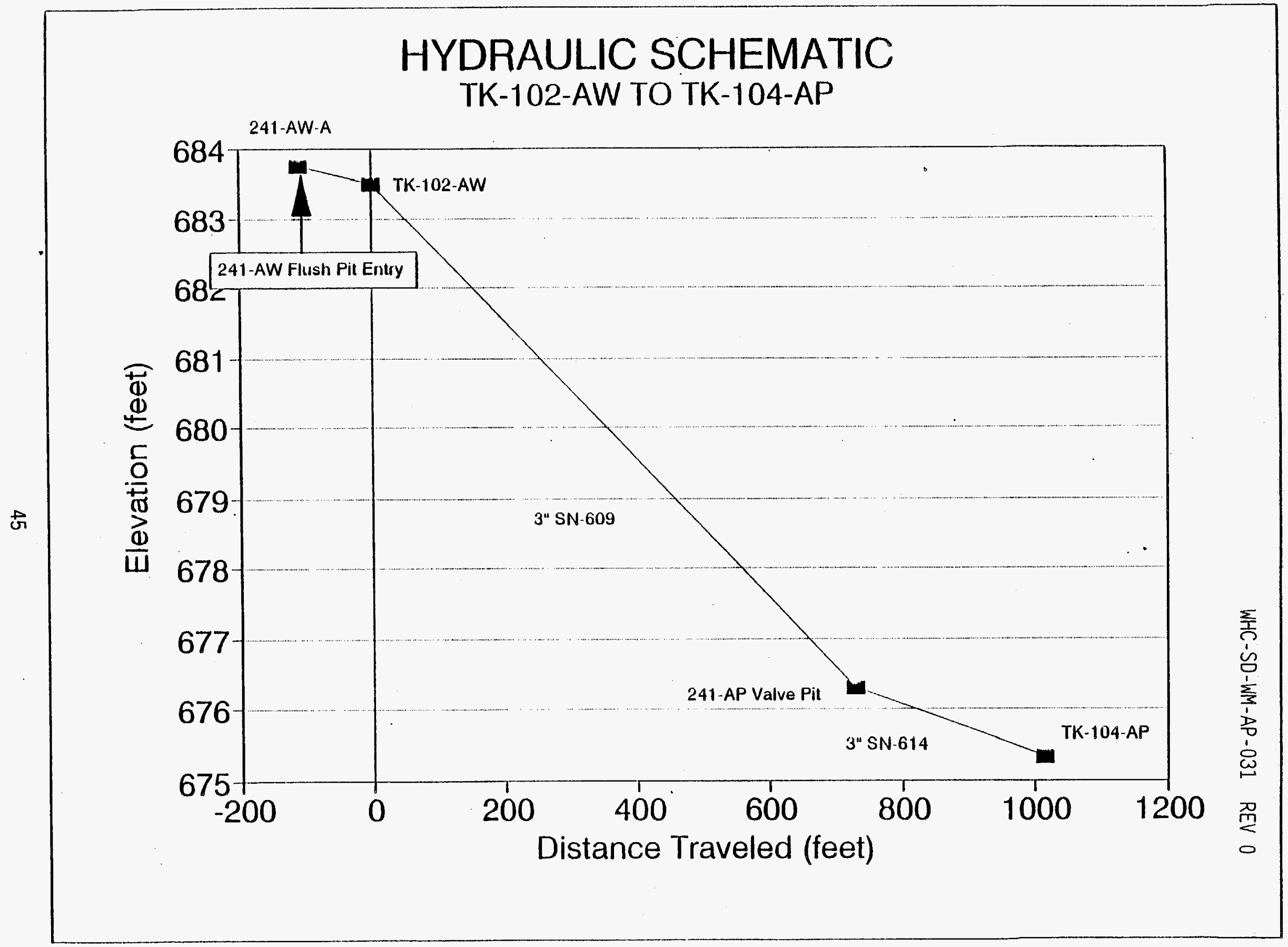




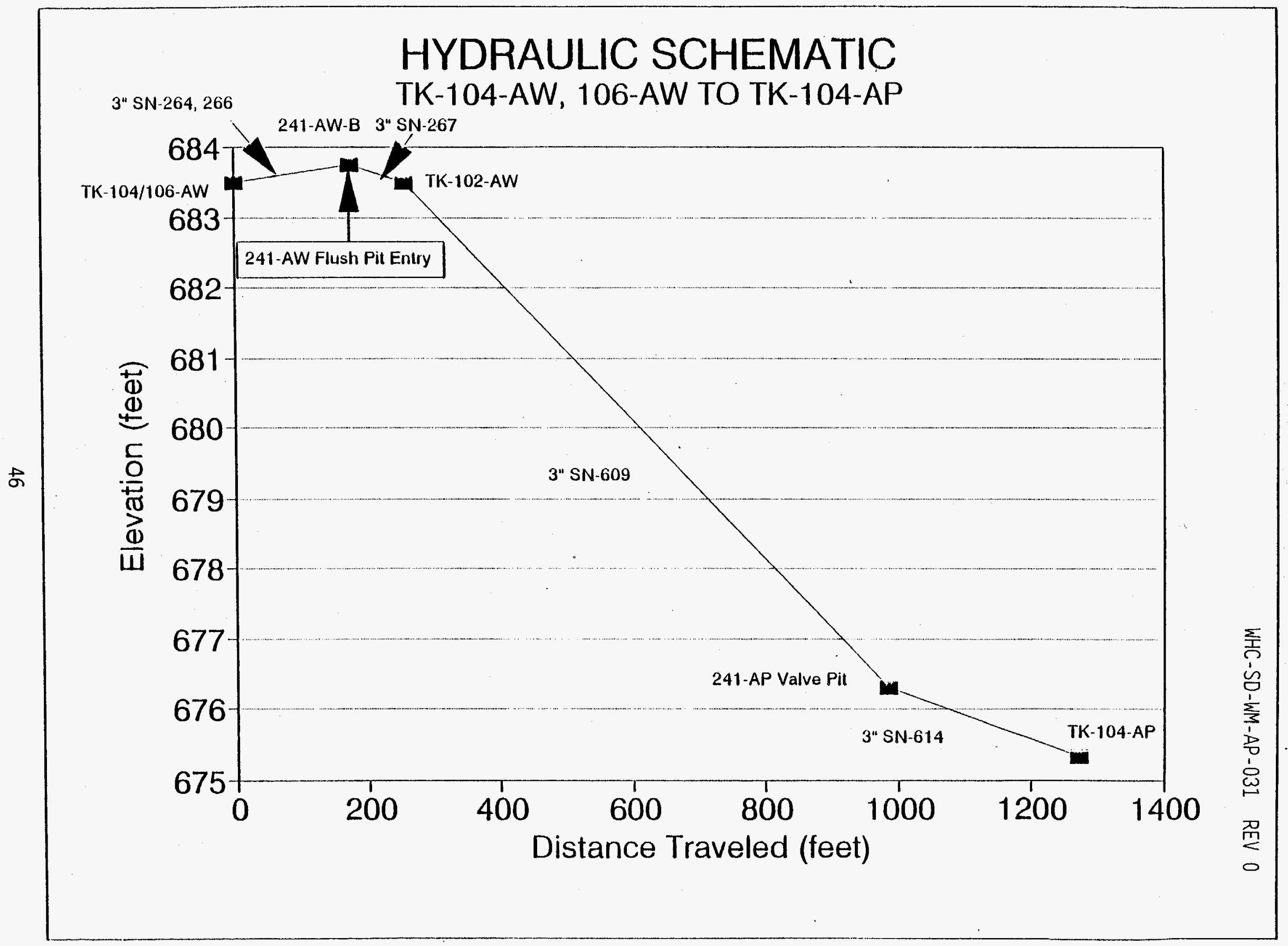


APPENDIX C: TRANSFER DATA, AP FARM

\section{Transfer Routes}

TK-101-AP

Route: Transfer Pump (01A Pit) to SN-611

SN-611 to 241-AP Valve Pit

SN-614 from 241-AP Valve Pit to TK-104-AP

Jumpers: Nozzle 18 to Nozzle 20 in 241-AP Valve Pit

TK-102-AP

Route: Transfer Pump (02A Pit) to SN-612

$\mathrm{SN}-612$ to $241-\mathrm{AP}$ Valve Pit

SN-614 from 241-AP Valve Pit to TK-104-AP

Jumpers: Nozzle 19 to Nozzle 20 in 241-AP Valve Pit

TK-103-AP

Route: Transfer Pump (03A Pit) to SN-613

SN-613 to 241-AP Valve Pit

SN-614 from 241-AP Valve Pit to TK-104-AP

Jumpers: Nozzle 17 to Nozzle 20 in 241-AP VaTve Pit

TK-105-AP

Route: Transfer Pump (05A Pit) to SN-615

SN-615 to 241-AP VaTve Pit

SN-614 from 241-AP Valve Pit to TK-104-AP

Jumpers: Nozzle 24 to Nozzle 20 in 241-AP Valve Pit

TK-106-AP

Route: Transfer Pump (06A Pit) to SN-616

SN-616 to 241-AP Valve Pit

SN-614 from 241-AP Valve Pit to TK-104-AP

Jumpers: Nozzle 21 to Nozzle 20 in 241-AP Valve Pit

TK-107-AP

Route: Transfer Pump (07A Pit) to SN-617

SN-617 to 241-AP Valve Pit

SN-614 from 241-AP Valve Pit to TK-104-AP 
Jumpers: Nozzle 23 to Nozzle 20 in 241-AP Valve Pit TK·108-AP

Route: Transfer Pump (08A Pit) to SN-618

SN-618 to 241-AP Valve Pit

SN-614 from 241-AP Valve Pit to TK-104-AP

Jumpers: Nozzle 22 to Nozzle 20 in 241-AP Valve Pit 
WHC-SD-WM-AP-031 REV 0

Valve Checklists

TK-101-AP TO TK-104-AP VALVE POSITION CHECKLIST

\begin{tabular}{|c|c|}
\hline Valve Designation (241-AP) & Valve Position \\
\hline 01A (AP-01A Central Pit) & $\begin{array}{l}\text { Route flow from Pump to Nozzle A. Block flow to } \\
\text { Nozzle E }\end{array}$ \\
\hline$V-609-1$ & CLOSED \\
\hline$V-609-2$ & CLOSED \\
\hline$V-609-3$ & CLOSED \\
\hline$V-610-1$ & CLOSED \\
\hline$V-610-2$ & CLOSED \\
\hline$V-610-3$ & CLOSED \\
\hline$V-611-1$ & $\begin{array}{c}\text { Route flow from valve } V-611-2 \text { To } V-612-1 \text {, Block } \\
\text { flow to Valve } V-613-1\end{array}$ \\
\hline$V-611-2$ & OPEN \\
\hline$V-612-1$ & $\begin{array}{c}\text { Route flow from Valve } V-611-1 \text { to } V-614-1 \text {, Block } \\
\text { flow to Valve } V-612-2\end{array}$ \\
\hline$V-612-2$ & CLOSED \\
\hline$V-613-1$ & $\begin{array}{c}\text { Route flow from Valve } V-613-2 \text { to } V-609-2 \text {, Block } \\
\text { flow to valve } V-611-1\end{array}$ \\
\hline$V-613-2$ & CLOSED \\
\hline$V-614-1$ & OPEN \\
\hline$V-615-1$ & CLOSED \\
\hline$V-616-1$ & $\begin{array}{c}\text { Route flow from valve } V-616-2 \text { to } V-618-1 \text {, Block } \\
\text { flow to valve } V-610-2\end{array}$ \\
\hline$V-616-2$ & CLOSED \\
\hline$V-617-1$ & $\begin{array}{c}\text { Route flow from valve } V-617-2 \text { to } V-615-1 \text {. Block } \\
\text { flow to valve } V-618-1\end{array}$ \\
\hline$V-617-2$ & CLOSED \\
\hline$V-618-1$ & $\begin{array}{c}\text { Route flow from Valve } V-616-1 \text { to } V-617-1 \text {, Block } \\
\text { flow to valve } V-618-2\end{array}$ \\
\hline$V-618-2$ & CLOSED \\
\hline$V-F L-1$ & CLOSED \\
\hline$V-F L-2$ & CLOSED \\
\hline$V-D R-1$ & CLOSED \\
\hline 04A (AP-04A Central Pit) & $\begin{array}{c}\text { Route flow from Nozzle A to Nozzle E. Block flow } \\
\text { to pump }\end{array}$ \\
\hline
\end{tabular}


TK-102-AP TO TK-104-AP VALVE POSITION CHECKLIST

\begin{tabular}{|c|c|}
\hline Valve Designation (241-AP) & Valve Position \\
\hline 02A (AP-02A Central Pit) & $\begin{array}{l}\text { Route flow from Pump to Nozzle A, Block flow to } \\
\text { Nozzle E }\end{array}$ \\
\hline$V-609-1$ & CLOSED \\
\hline$V-609-2$ & CLOSED \\
\hline$V-609-3$ & CLOSED \\
\hline$V-610-1$ & CLOSED \\
\hline$V-610-2$ & CLOSED \\
\hline$V-610-3$ & CLOSED \\
\hline$V-611-1$ & $\begin{array}{l}\text { Route flow from Valve } V-611-2 \text { To } V-613-1 \text {, Block } \\
\text { flow to Valve } V-612-1\end{array}$ \\
\hline$V-611-2$ & CLOSED \\
\hline$V-612-1$ & $\begin{array}{c}\text { Route flow from Valve } V-612-2 \text { to } V-614-1 \text {, Block } \\
\text { flow to Valve } V-611-1\end{array}$ \\
\hline$V-612-2$ & OPEN \\
\hline$V-613-1$ & $\begin{array}{c}\text { Route flow from Valve } V-613-2 \text { to } V-609-2 \text {, Block } \\
\text { flow to Valve } V-611-1\end{array}$ \\
\hline$V-613-2$ & CLOSED \\
\hline$V-614-1$ & OPEN \\
\hline$V-615-1$ & CLOSED \\
\hline$V-616-1$ & $\begin{array}{c}\text { Route flow from valve } V-616-2 \text { to } V-618-1 \text {, Block } \\
\text { flow to valve } V-610-2\end{array}$ \\
\hline$V-616-2$ & CLOSED \\
\hline$V-617-1$ & $\begin{array}{c}\text { Route flow from valve } v-617-2 \text { to } v-615-1 \text {, Block } \\
\text { flow to valve } v-618-1\end{array}$ \\
\hline$V-617-2$ & CLOSED \\
\hline$V-618-1$ & $\begin{array}{c}\text { Route flow from valve } V-616-1 \text { to } V-617-1 \text {, Block } \\
\text { flow to valve } V-618-2\end{array}$ \\
\hline$V-618-2$ & CLOSED \\
\hline$V-F L-1$ & CLOSED \\
\hline$V-F L-2$ & CLOSED \\
\hline$V-D R-1$ & CLOSED \\
\hline 04A (AP-04A Central Pit) & $\begin{array}{c}\text { Route flow from Nozzle A to Nozzle E, Block flow } \\
\text { to pump }\end{array}$ \\
\hline
\end{tabular}


WHC-SD-WM-AP-031 REV 0

TK-103-AP TO TK-104-AP VALVE POSITION CHECKLIST

\begin{tabular}{|c|c|}
\hline Valve Designation (241-AP) & Valve Position \\
\hline 03A (AP-03A Central Pit) & $\begin{array}{c}\text { Route flow from Pump to Nozzle A, Block flow to } \\
\text { Nozzle. E }\end{array}$ \\
\hline$V-609-1$ & CLOSED \\
\hline$V-609-2$ & CLOSED \\
\hline$V-609-3$ & CLOSED \\
\hline$V-610-1$ & CLOSED \\
\hline$V-610-2$ & CLOSED \\
\hline$V-610-3$ & CLOSED \\
\hline$V-611-1$ & $\begin{array}{l}\text { Route flow from Valve } V-613-1 \text { To } V-612-1 \text {. Block } \\
\text { flow to Valve } V-611-2\end{array}$ \\
\hline$V-611-2$ & CLOSED \\
\hline$V-612-1$ & $\begin{array}{c}\text { Route flow from Valve } V-611-1 \text { to } V-614-1 \text {, Block } \\
\text { flow to Valve } V-612-2\end{array}$ \\
\hline$V-612-2$ & CLOSED \\
\hline$V-613-1$ & $\begin{array}{c}\text { Route flow from Valve } V-613-2 \text { to } V-611-1 \text {, Block } \\
\text { flow to Valve } V-609-2\end{array}$ \\
\hline$V-613-2$ & OPEN \\
\hline$V-614-1$ & OPEN \\
\hline$V-615-1$ & CLOSED \\
\hline$V-616-1$ & $\begin{array}{c}\text { Route flow from Valve } V-616-2 \text { to } V-618-1 \text {, Block } \\
\text { flow to Valve } V-610-2\end{array}$ \\
\hline$V-616-2$ & CLOSED \\
\hline$V-617-1$ & $\begin{array}{c}\text { Route flow from Valve } V-617-2 \text { to } V-615-1 \text {, Block } \\
\text { flow to Valve } V-618-1\end{array}$ \\
\hline$V-617-2$ & CLOSED \\
\hline$V-618-1$ & $\begin{array}{c}\text { Route flow from Valve } V-616-1 \text { to } V-617-1, \text { Block } \\
\text { flow to valve } V-618-2\end{array}$ \\
\hline$V-618-2$ & CLOSED \\
\hline$V-F L-1$ & CLOSED \\
\hline$V-F L-2$ & CLOSED \\
\hline$V-D R-I$ & CLOSED \\
\hline 04A (AP-04A Central Pit) & $\begin{array}{c}\text { Route flow from Nozzle A to Nozzle E, Block flow } \\
\text { to Pump }\end{array}$ \\
\hline
\end{tabular}


TK-105-AP TO TK-104-AP VALVE POSITION CHECKLIST

\begin{tabular}{|c|c|}
\hline Valve Designation (241-AP) & Valve Position \\
\hline 05A (AP-05A Central Pit) & $\begin{array}{l}\text { Route flow from Pump to Nozzle A, Block flow to } \\
\text { Nozzle E }\end{array}$ \\
\hline$V-609-1$ & CLOSED \\
\hline$V-609-2$ & OPEN \\
\hline$V-609-3$ & OPEN \\
\hline$V-610-1$ & CLOSED \\
\hline$v-610-2$ & OPEN \\
\hline$V-610-3$ & OPEN \\
\hline$V-611-1$ & $\begin{array}{c}\text { Route flow from Valve V-613-1 To } V-612-1 \text {. Block } \\
\text { flow to Valve } V-611-2\end{array}$ \\
\hline$V-611-2$ & CLOSED \\
\hline$V-612-1$ & $\begin{array}{c}\text { Route flow from Valve } V-611-1 \text { to } V-614-1 \text {. Block } \\
\text { flow to Valve } V-612-2\end{array}$ \\
\hline$V-612-2$ & CLOSED \\
\hline$V-613-1$ & $\begin{array}{c}\text { Route flow from Valve } V-609-2 \text { to } V-611-1 \text {, Block } \\
\text { flow to Valve } V-613-2\end{array}$ \\
\hline$\dot{V}-613-2$ & CLOSED \\
\hline$V-614-1$ & OPEN \\
\hline$V-615-1$ & OPEN \\
\hline$V-616-1$ & $\begin{array}{c}\text { Route flow from Valve } V-618-1 \text { to } V-610-2 \text {. Block } \\
\text { flow to valve } V-616-2\end{array}$ \\
\hline$V-616-2$ & CLOSED \\
\hline$V-617-1$ & $\begin{array}{c}\text { Route flow from Valve } V-615-1 \text { to } V-618-1 \text {, Block } \\
\text { flow to Valve } V-617-2\end{array}$ \\
\hline$V-617-2$ & CLOSED \\
\hline$V-618-1$ & $\begin{array}{c}\text { Route flow from Valve V-617-1 to } V-616-1 \text {, Block } \\
\text { flow to valve } V-618-2\end{array}$ \\
\hline$V-618-2$ & CLOSED \\
\hline$V-F L-1$ & CLOSED \\
\hline$V-F L-2$ & CLOSED \\
\hline$V-D R-1$ & CLOSED \\
\hline 04A (AP-04A Central Pit) & $\begin{array}{c}\text { Route flow from Nozzle A to Nozzle E, Block flow } \\
\text { to Pump }\end{array}$ \\
\hline
\end{tabular}


TK-106-AP TO TK-104-AP VALVE POSITION CHECKLIST

\begin{tabular}{|c|c|}
\hline Valve Designation (241-AP) & Valve Position \\
\hline 06A (AP-06A Central Pit) & $\begin{array}{l}\text { Route flow from Pump to Nozzle A. Block flow to } \\
\text { Nozzle E }\end{array}$ \\
\hline$V-609-1$ & CLOSED \\
\hline$V-609-2$ & OPEN \\
\hline$V-609-3$ & OPEN \\
\hline$V-610-1$ & CLOSED \\
\hline$V-610-2$ & OPEN \\
\hline$V-610-3$ & OPEN \\
\hline$V-611-1$ & $\begin{array}{c}\text { Route flow from Valve } V-613-1 \text { To } V-612-1 \text {, Block } \\
\text { flow to Valve } V-611-2\end{array}$ \\
\hline$V-611-2$ & CLOSED \\
\hline$V-612-1$ & $\begin{array}{c}\text { Route flow from Valve } V-611-1 \text { to } V-614-1 \text {, Block } \\
\text { flow to Valve } V-612-2\end{array}$ \\
\hline$V-612-2$ & CLOSED \\
\hline$V-613-1$ & $\begin{array}{c}\text { Route flow from valve } V-609-2 \text { to } V-611-1 \text {, Block } \\
\text { flow to valve } V-613-2\end{array}$ \\
\hline$V-613-2$ & CLOSED \\
\hline$V-614-1$ & OPEN \\
\hline$V-615-1$ & CLOSED \\
\hline$V-616-1$ & $\begin{array}{c}\text { Route flow from Valve } V-616-2 \text { to } V-610-2 \text {, Block } \\
\text { flow to Valve } V-618-1\end{array}$ \\
\hline$V-616-2$ & OPEN \\
\hline$V-617-1$ & $\begin{array}{c}\text { Route flow from Valve } V-615-1 \text { to } V-618-1 \text {, Block } \\
\text { flow to Valve } V-617-2\end{array}$ \\
\hline$V-617-2$ & CLOSED \\
\hline$V-618-1$ & $\begin{array}{c}\text { Route flow from Valve } V-617-1 \text { to } V-616-1 \text {, Block } \\
\text { flow to Valve } V-618-2\end{array}$ \\
\hline$V-618-2$ & CLOSED \\
\hline$V-F L-1$ & CLOSED \\
\hline$V-F L-2$ & CLOSED \\
\hline$V-D R-1$ & CLOSED \\
\hline 04A (AP-04A Central Pit) & $\begin{array}{c}\text { Route flow from Nozzle A to Nozzle E, Block flow } \\
\text { to pump }\end{array}$ \\
\hline
\end{tabular}


TK-107-AP TO TK-104-AP VALVE POSITION CHECKLIST

\begin{tabular}{|c|c|}
\hline Valve Designation (241-AP) & Valve Position \\
\hline 07A (AP-07A Central Pit) & $\begin{array}{c}\text { Route flow from pump to Nozzle A, Block flow to } \\
\text { Nozzle E }\end{array}$ \\
\hline$V-609-1$ & CLOSED \\
\hline$V-609-2$ & OPEN \\
\hline$V-609-3$ & OPEN \\
\hline$V-610-1$ & CLOSED \\
\hline$V-610-2$ & OPEN \\
\hline$V-610-3$ & OPEN \\
\hline$V-611-1$ & $\begin{array}{c}\text { Route flow from Valve } V-613-1 \text { To } V-612-1 \text {. Block } \\
\text { flow to Valve } V-611-2\end{array}$ \\
\hline$V-611-2$ & CLOSED \\
\hline$V-612-1$ & $\begin{array}{c}\text { Route flow from Valve } V-611-1 \text { to } V-614-1, \text { Block } \\
\text { flow to Valve } V-612-2\end{array}$ \\
\hline$V-612-2$ & CLOSED \\
\hline$V-613-1$ & $\begin{array}{c}\text { Route flow from Valve } V-609-2 \text { to } V-611-1 \text {. Block } \\
\text { flow to valve } V-613-2\end{array}$ \\
\hline$V-613-2$ & CLOSED \\
\hline$V-614-1$ & OPEN \\
\hline$V-615-1$ & CLOSED \\
\hline$V-616-1$ & $\begin{array}{l}\text { Route flow from Valve } V-618-1 \text { to } V-610-2 \text {, Block } \\
\text { flow to Valve } V-616-2\end{array}$ \\
\hline$V-616-2$ & CLOSED \\
\hline$V-617-1$ & $\begin{array}{c}\text { Route flow from Valve } V-617-2 \text { to } V-618-1 \text {, Block } \\
\text { flow to valve } V-615-1\end{array}$ \\
\hline$V-617-2$ & OPEN \\
\hline$V-618-1$ & $\begin{array}{c}\text { Route flow from Valve } V-617-1 \text { to } V-616-1 \text {, Block } \\
\text { flow to Valve } V-618-2\end{array}$ \\
\hline$V-618-2$ & CLOSED \\
\hline$V-F L-1$ & CLOSED \\
\hline$V-F L-2$ & CLOSED \\
\hline$V-D R-1$ & CLOSED \\
\hline 04A (AP-04A Central Pit) & $\begin{array}{c}\text { Route flow from Nozzle A to Nozzle E, Block flow } \\
\text { to pump }\end{array}$ \\
\hline
\end{tabular}


TK-108-AP TO TK-104-AP VALVE POSITION CHECKLIST

\begin{tabular}{|c|c|}
\hline Valve Designation (241-AP) & Valve Position \\
\hline 08A (AP-08A Central Pit) & $\begin{array}{c}\text { Route flow from pump to Nozzle A, Block flow to } \\
\text { Nozzle E }\end{array}$ \\
\hline$V-609-1$ & CLOSED \\
\hline$V-609-2$ & OPEN \\
\hline$V-609-3$ & OPEN \\
\hline$V-610-1$ & CLOSED \\
\hline$V-610-2$ & OPEN \\
\hline$V-610-3$ & OPEN \\
\hline$V-611-1$ & $\begin{array}{c}\text { Route flow from Valve } V-613-1 \text { To } V-612-1 \text {, Block } \\
\text { flow to Valve } V-611-2\end{array}$ \\
\hline$V-611-2$ & CLOSED \\
\hline$V-612-1$ & $\begin{array}{c}\text { Route flow from Valve } V-611-1 \text { to } V-614-1 \text {, Block } \\
\text { flow to valve } V-612-2\end{array}$ \\
\hline$V-612-2$ & CLOSED \\
\hline$V-613-1$ & $\begin{array}{c}\text { Route flow from Valve } V-609-2 \text { to } V-611-1 \text {, Block } \\
\text { flow to Valve } V-613-2\end{array}$ \\
\hline$V-613-2$ & CLOSED \\
\hline$V-614-1$ & OPEN \\
\hline$V-615-1$ & CLOSED \\
\hline$V-616-1$ & $\begin{array}{c}\text { Route flow from Valve } V-618-1 \text { to } V-610-2 \text {, Block } \\
\text { flow to Valve } V-616-2\end{array}$ \\
\hline$V-616-2$ & CLOSED \\
\hline$V-617-1$ & $\begin{array}{c}\text { Route flow from Valve } V-617-2 \text { to } V-615-1 \text {, Block } \\
\text { flow to valve } V-618-1\end{array}$ \\
\hline$V-617-2$ & CLOSED \\
\hline$V-618-1$ & $\begin{array}{c}\text { Route flow from Valve } V-618-2 \text { to } V-616-1 \text {, Block } \\
\text { flow to valve } V-617-1\end{array}$ \\
\hline$V-618-2$ & OPEN \\
\hline $\mathrm{V}-\mathrm{FL}-1$ & CLOSED \\
\hline$V-F L-2$ & CLOSED \\
\hline$V-D R-1$ & CLOSED \\
\hline 04A (AP-04A Central Pit) & $\begin{array}{c}\text { Route flow from Nozzle A to Nozzle E, Block flow } \\
\text { to pump }\end{array}$ \\
\hline
\end{tabular}




\section{Leak Detection Equipment}

101-AP

Type

LFT-101-1

Manual Tape

LDE-01A-1

LDE-VP-1

LDE-04A-1

Manua 7 Tape

LIT-104-1

102-AP

LIT-102-1

Manual Tape

LDE-02A-1

LDE-VP-1

LDE-04A-1

Manual Tape

LIT-104-1

103-AP

LIT-103-1

Manual Tape

LDE-03A-1

LDE-VP-1

LDE-04A-1

Manua 7 Tape

LIT-104-1

105-AP

LIT-105-1

Manual Tape

LDE-05A-1

LDE-VP-1

LDE-04A-1

Manual Tape

LIT-104-1

\section{Location}

TK-101-AP

TK-101-AP

AP-01A

241-AP VP

AP-04A

TK-104-AP

TK-104-AP

TK-102-AP

TK-102-AP

AP-02A

241-AP VP

AP-04A

TK-104-AP

TK-104-AP

TK-103-AP

TK-103-AP

$A P-03 A$

241-AP VP

AP-04A

TK-104-AP

TK-104-AP

TK-105-AP

TK-105-AP

AP-05A

241-AP VP

AP-04A

TK-104-AP

TK-104-AP

\section{CBRS Description}

AP102-2

TK-101-AP Manual Tape

AP153-1

AP801-1

AP165-1

TK-104-AP

AP105-2

AP103-2

TK-102-AP Manual Tape

AP156-1

AP801-1

AP165-1

TK-104-AP

AP105-2

AP104-2

TK-103-AP Manual Tape

AP159-1

AP801-1

AP165-1

TK-104-AP

AP105-2

AP106-2

TK-105-AP Manual Tape

AP168-1

AP801-1

AP165-1

TK-104-AP

AP105-2 
WHC-SD-WM-AP-031 REV 0

106-AP

\section{Type}

LIT-106-1

Manual Tape

LDE-06A-1

LDE-VP-1

LDE-04A-1

Manual Tape

LIT-104-1

107-AP

LIT-107-1

Manual Tape

LDE-07A-1

LDE-VP-1

LDE-04A-1

Manual Tape

LIT-104-1

108-AP

LIT-108-1

Manual Tape

LDE-08A-1

LDE-VP-1

LDE-04A-1

Manual Tape

LIT-104-1

\section{Location}

TK-106-AP

TK-106-AP

AP-06A

241-AP VP

AP-04A

TK-104-AP

TK-104-AP

TK-107-AP

TK-107-AP

AP-07A

241-AP VP

AP-04A

TK-104-AP

TK-104-AP

TK-108-AP

TK-108-AP

AP-08A

241-AP VP

AP-04A

TK-104-AP

TK-104-AP
CBRS Description

AP107-2

TK-106-AP Manual Tape

AP173-1

AP801-1

AP165-1

TK-104-AP

AP105-2

AP108-2

TK-107-AP Manua1 Tape

AP176-1

AP801-1

AP165-1

TK-104-AP

AP105-2

AP109-2

TK-108-AP Manual Tape

AP179-1

AP801-1

AP165-1

TK-104-AP

AP105-2 
WHC-SD-WM-AP-031 REV 0

Hydraul ic Diagram, AP Farm 


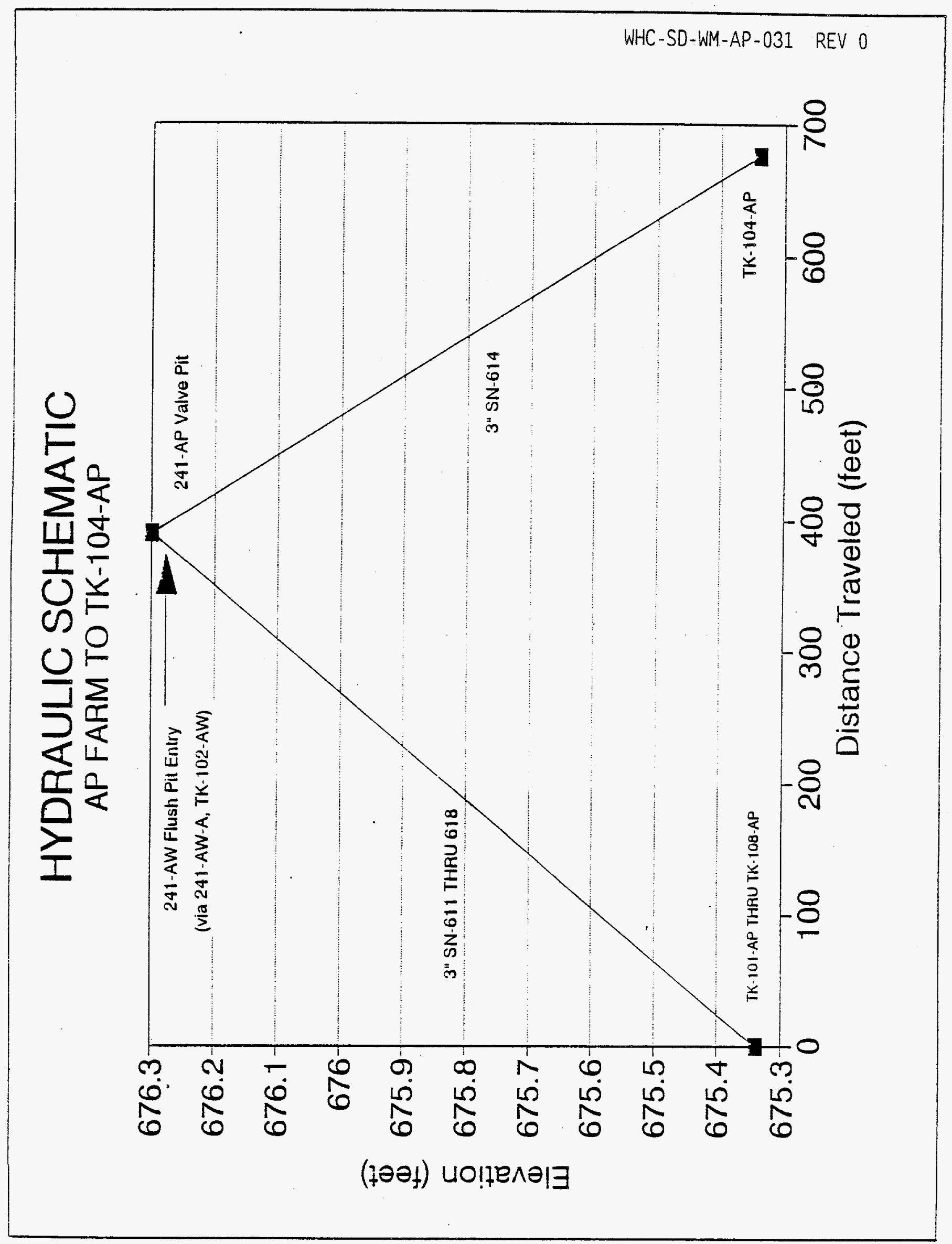


APPENDIX D: TRANSFER DATA, AY FARM

\section{Transfer Routes}

TK-101-AY

Route: Transfer Pump (01A Pit) to SL-504

SL-504 to 02A Pit

SL-503 to 02D Pit

Continue with Procedure for transfer from TK-102-AY to TK-104-AP, WTWP-94-0009

Jumpers: Flex jumper from pump to Nozzle U-2 in 01A Pit

Nozzle U-8 to Nozzle U-3 in 02A Pit

Nozzle U-2 to Nozzle U-3 in 02D Pit

Continue with Procedure for transfer from TK-102-AY to TK-104-AP. WTWP-94-0009

TK-102-AY

Route: Follow procedure WTWP-94-0009

Jumpers: Follow procedure WTWP-94-0009 


$$
\text { WHC-SD-WM-AP-031 REV } 0
$$

\section{Valve Checklists}

TK-101-AY TO TK-104-AP VALVE POSITION CHECKLIST

\begin{tabular}{||c|c|}
\hline Valve Description & Valve Position \\
\hline AY-01D Pit & Jumper from pump to Nozzle U-2 \\
\hline V-02A (AY-02A Pit) & $\begin{array}{r}\text { Route flow from Nozzle U-8 to Nozzle } \\
\text { U-3, Block Distributor }\end{array}$ \\
\hline V-02D (AY-02D Pit) & $\begin{array}{c}\text { Route flow from Nozzle U-2 to Nozzle } \\
\text { U-3, Block flow to the pump }\end{array}$ \\
\hline $\begin{array}{l}\text { Continue with the procedure for } \\
\text { TK-102-AY to TK-104-AP transfer }\end{array}$ & \\
\hline & \\
\hline & \\
\hline
\end{tabular}




\section{TK-102-AY TO TK-104-AP VALVE POSITION CHECKLIST}

\begin{tabular}{|c|c|}
\hline Valve Description & Valve Position \\
\hline V-02A (241-AY-02A Pump Pit) & Route flow from Distributor to Nozzle U-8 \\
\hline V-02D (241-AY-02D Pump Pit) & Route flow from pump to Nozzle U-3 \\
\hline $\begin{array}{c}\text { SL-502 Encasement Drain (241-AY-02D Pump } \\
\text { Pit) }\end{array}$ & OPERATE \\
\hline $\begin{array}{l}\text { SN-201/214 Encasement Drain A-21 (241- } \\
\text { AX-A Valve Pit) }\end{array}$ & SEAL LOOP \\
\hline 14A (241-AW-A Valve Pit) & OPEN \\
\hline $12 \mathrm{~A}$ (241-AW-A Valve Pit) & OPEN \\
\hline 13A (241-AW-A Valve Pit) & CLOSED \\
\hline $\begin{array}{c}\text { SN-220 Encasement Drain A-17 (241-AW-A } \\
\text { Valve Pit) }\end{array}$ & OPERATE \\
\hline B-5 (241-AW-Flush Pit) & Block flow from valve $B-4$ \\
\hline B-3 (241-AW Flush Pit) & Block flow from valve $B-4$ \\
\hline B-1 (241-Aw Flush Pit) & CLOSED \\
\hline B-7 (241-AW Flush Pit) & CLOSED \\
\hline B-8 (241-AW Flush Pit) & CLOSED \\
\hline B-9 (241-AW Flush Pit) & CLOSED \\
\hline B-10 (241-AW Flush Pit) & CLOSED \\
\hline B-11 (241-AW Flush Pit) & CLOSED \\
\hline B-12 (241-AW Flush Pit) & CLOSED \\
\hline B-14 (241-AW Flush Pit) & CLOSED \\
\hline B-4 (241-AW Flush Pit) & Route flow from valve $B-3$ to valve $B-10$ \\
\hline V-267-1 (241-AW-02A Pump Pit) & Route flow from Nozzle $\mathrm{J}$ to Nozzle $\mathrm{V}$ \\
\hline$V-267-2$ (241-AW-02A Pump Pit) & CLOSED \\
\hline V-268-1 (241-AW-02A Pump Pit) & Route flow from Nozzle $H$ to Valve $V-268-2$ \\
\hline$V-268-2$ (241-AW-02A Pump Pit) & CLOSED \\
\hline $\begin{array}{c}\text { SN-267 Encasement Drain 02A-2 (241-AW- } \\
\text { 02A Pump Pit) }\end{array}$ & OPERATE \\
\hline$V-609-1$ & OPEN \\
\hline$V-609-2$ & OPEN \\
\hline$V-609-3$ & CLOSED \\
\hline$V-610-1$ & CLOSED \\
\hline
\end{tabular}


WHC-SD-WM-AP-031 REV 0

\begin{tabular}{|c|c|}
\hline$V-610-2$ & CLOSED \\
\hline$V-610-3$ & CLOSED \\
\hline$V-611-1$ & $\begin{array}{l}\text { Route flow from valve } V-613-1 \text { To } V-612-1 \text {, } \\
\text { Block flow to Valve } V-611-2\end{array}$ \\
\hline$V-611-2$ & CLOSED \\
\hline$V-612-1$ & $\begin{array}{l}\text { Route flow from Valve } V-611-1 \text { to } V-614-1 \text {, } \\
\text { Block flow to Valve } V-612-2\end{array}$ \\
\hline$V-612-2$ & CLOSED \\
\hline$V-613-1$ & $\begin{array}{l}\text { Route flow from Valve } V-609-2 \text { to } V-611-1 \text {, } \\
\text { Block flow to Valve } V-613-2\end{array}$ \\
\hline$V-613-2$ & CLOSED \\
\hline$V-614-1$ & OPEN \\
\hline$V-615-1$ & CLOSED \\
\hline$V-616-1$ & $\begin{array}{l}\text { Route flow from Valve } V-616-2 \text { to } V-618-1 \text {, } \\
\text { Block flow to Valve } V-610-2\end{array}$ \\
\hline$V-616-2$ & CLOSED \\
\hline$V-617-1$ & $\begin{array}{l}\text { Route flow from vaive } V-617-2 \text { to } V-615-1 \text {, } \\
\text { Block flow to valve } V-618-1\end{array}$ \\
\hline$V-617-2$ & CLOSED \\
\hline$V-618-1$ & Block flow to Valve $V-616-1$ \\
\hline$V-618-2$ & CLOSED \\
\hline $\mathrm{V}-\mathrm{FL}-1$ & CLOSED \\
\hline$V-F L-2$ & CLOSED \\
\hline V-DR-1 & CLOSED \\
\hline 04A (241-AP-04A Pump Pit) & $\begin{array}{c}\text { Route flow from Nozzle A to Nozzle E, Block } \\
\text { flow to pump }\end{array}$ \\
\hline V-4 Seal Loop (241-AP-Valve Pit) & OPERATE \\
\hline
\end{tabular}


Leak Detection Equipment

101-AY
Type
LIT-101-AY
Manua1 Tape
LDE-101-20
LDE-SL-504
LDE-102-22
LDE-SL-503
LDE-102-20
LDE-SL-502
LDE-241-AX-B
LDE-241-AX-A
PS-SN-214
LDE-241-A-A-VP
WFT-350-1
LDE-241AW-SN-220
LDE-VP-AW-A
LDE-241AW-SN267
LDE-2A-1
LDE-609
LDE-VP-1
LDE-04A-1
ManUa1 Tape
LIT-104-1

Location
TK-101-AY
TK-101-AY
AY-01D
SL-504
AY-02A
SL-503
AY-02D
SL-502
$241-A X-B$
$241-A X-A$
SN-214/201
$241-A-A$
A-350 Catch Tank
SN-220
$241-A W-A$
SN-267 (AW)
AW-02A
SN-609
$241-A P$ VP
AP-04A
TK-104-AP
TK-104-AP

\section{CBRS Description}

AY085-1

TK-101-AY Manual Tape

AY075-1

AY036-1

AY033-1

AY035-1

AY027-1

AY088-1

AX178-1

AX177-1

AY191/AY188-1

2R072-1

AE073-4

AW068-1

AW004-1

AW069-1

AW086-1

AP151-1

AP801-1

AP165-1

TK-104-AP

AP105-2

102-AY

LIT-102-AY
Manua T Tape
LDE-102-22
LDE-SL-503
LDE-102-20
LDE-SL-502
LDE-241-AX-B
LDE-241-AX-A
PS-SN-214
LDE-241-A-A-VP
WFT-350-1
LDE-241AW-SN-220
LDE-VP-AW-A
LDE-241AW-SN267
LDE-2A-1
LDE-609
LDE-VP-1
LDE-04A-1
Manua1 Tape
LIT-104-1
TK-102-AY
TK-102-AY
AY $-02 A$
$S L-503$
AY -020
$S L-502$
241-AX-B
$241-A X-A$
SN-214/201
241-A-A
A-350 Catch Tank
$\mathrm{SN}-220$
241-AW-A
SN-267 (AW)
AW-02A
SN-609
241-AP VP
AP-04A
TK-104-AP
TK-104-AP

AY040-1

TK-102-AY Manual Tape

AY033-1

AY035-1

AY027-1

AY088-1

AX178-1

AX177-1

AY191/AY188-1

2R072-1

AE073-4

AW068-1

AW004-1

AW069-1

AW086-1

AP151-1

AP801-1

AP165-1

TK-104-AP

AP105-2 
WHC-SD-WM-AP-031 REV 0

Hydraulic Diagrams, AY Farm 


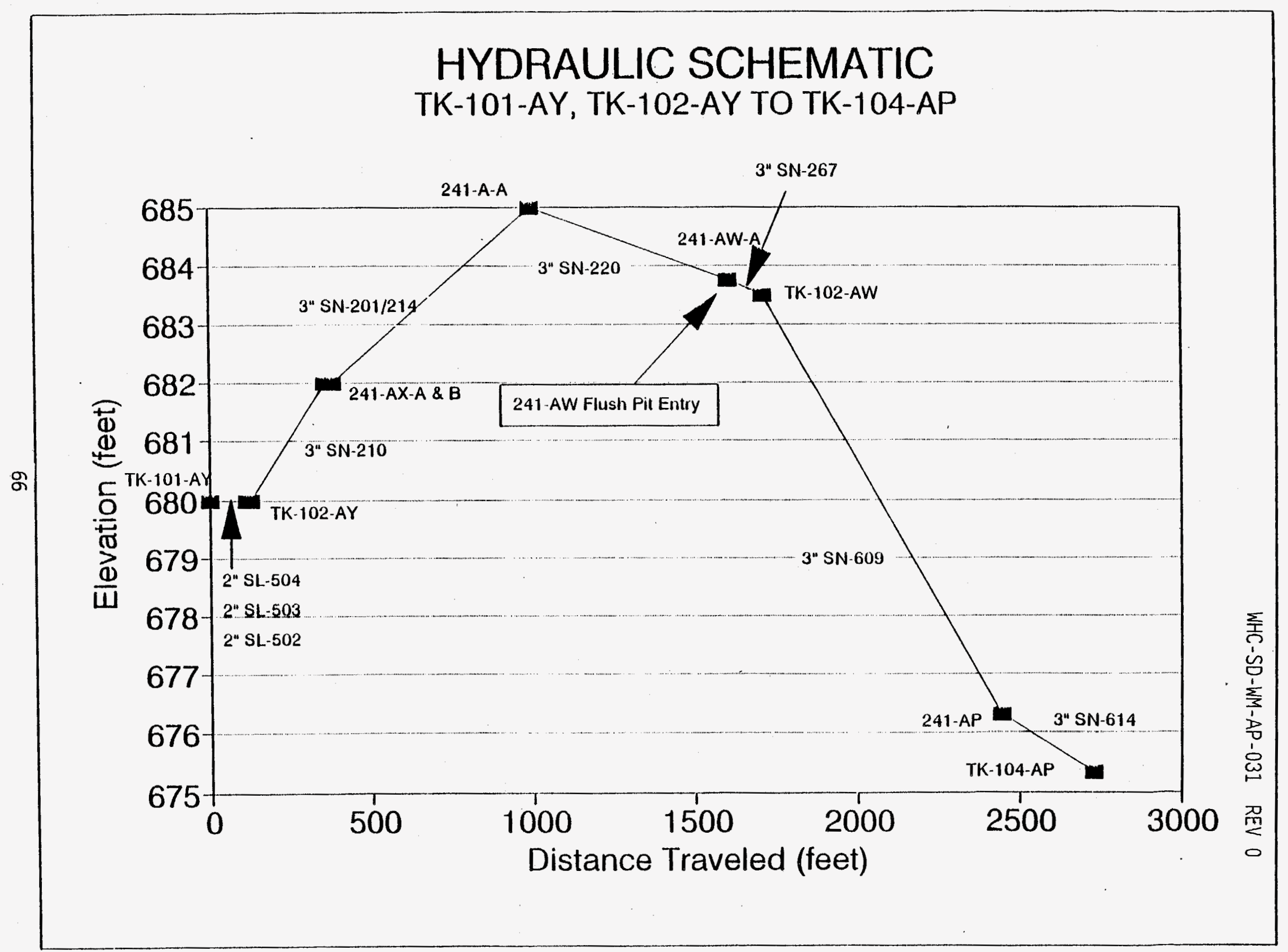


WHC-SD-WM-AP-031 REV 0

\section{APPENDIX E: TRANSFER DATA, SY FARM}

\section{Transfer Routes}

\section{TK-101-SY (to 102-SY)}

Route: Transfer Pump (01A Pit) to SN-278

SN-278 from TK-101-SY to 241-SY-B

SN-286 from 241-SY-B to 102-SY-02A Pit

Jumpers: Nozzle R-16 to R-11 in 241-SY-B Valve Pit

TK-102-SY

Route: Transfer Pump (02A Pit) to SN-285

SN-285 from TK-102-SY to 241-SY-A

SN-280 from $241-S Y-A$ to $241-S Y-B$

$V-561$ from $241-S Y-B$ to $244-S$ Catch Station

$V-522$ from 244-S Catch Station to 241-S-151 Diversion Box

$V-503$ (4700) from 241-S-151 Diversion Box to 241-UX-154

$V-360$ from $241-U X-154$ to $241-E R-151$

$V-228$ from $241-E R-151$ to $241-E R-153$

SN-232 from 241-ER-153 to 244A Lift Station

SN-215 from 244A Lift Station to 241-A-A

$S N-204$ from $241-A-A$ Valve Pit to $241-A-B$ Valve Pit

$S N-213 / 200$ from $241-A-B$ Valve Pit to $241-A X-B-V a 7 v e$ Pit

SL-502 from 241-AX-B Valve Pit to TK-102-AY

Jumpers: Nozzle L-11 to Nozzle L-19 in 241-SY-A Valve pit

Nozzle R-19 to R-15 in 241-SY-B Valve Pit

Nozzle 4 to Nozzle 5 in 244-S Catch Station

Nozzle $\mathrm{C}-1$ to Nozzle $\mathrm{U}-1$ in 241-S-151 Diversion Box

Nozzle L-8 to Nozzle L-1 in 241 UX-154 Diversion Box

Vent Valve $V-360$ in 241-EW-151 Vent Station

Nozzle U-2 to Nozzle U-10 in 241-ER-151 Diversion Box

Nozzle 2 to Nozzle 3 in 241-ER-153 Diversion Box

Nozzle P-3 to Nozzle P-7 in 244-A Lift Station

Nozzle L-16 to Nozzle L-19 in 241-A-A Valve Pit

Nozzle R-19 to Nozzle R-1 in 241-A-B Valve Pit

Nozzle R-1 to Nozzle R-16 in 241-AX-B Valve Pit

TK-103-SY (to 102-SY)

Route: Transfer Pump (03A Pit) to SN-279

SN-279 from TK-103-SY to 241-SY-B

SN-286 from 241-SY-B to 102-SY-02A Pit

Jumpers: Nozzle R-14 to R-11 in 241-SY-B Valve Pit 
WHC-SD-WM-AP-03I REV 0

\section{Valve Checklists}

TK-101-SY TO TK-102-SY VALVE POSITION CHECKLIST

\begin{tabular}{|c|c|}
\hline Valve Description & Valve Position \\
\hline \hline 101-SY-01A Pit & Insta17 Jumper from pump to Nozzle A \\
\hline B-15 (241-SY-B Valve Pit) & $\begin{array}{c}\text { Route flow from Valve R-16 to Valve } \\
\text { B-16, Block flow to Nozzle R-19 }\end{array}$ \\
\hline B-16 (241-SY-B Valve Pit) & $\begin{array}{c}\text { Route flow from Valve B-15 to Nozzle } \\
\text { R-11, Block flow to Nozzle R-14 }\end{array}$ \\
\hline B-25 (241-SY-B Valve Pit) & OPEN \\
\hline B-26 (241-SY-B Valve Pit) & CLOSED \\
\hline A-4 (102-SY-02A Pit) & Route flow from Nozzle H to Tank, Valve A-3 \\
\hline A-3 (102-SY-02A Pit) & CLOSED \\
\hline A-5 (102-SY-02A Pit) & OPEN \\
\hline
\end{tabular}


WHC-SD-WM-AP-031 REV 0

TK-102-SY TO TK-102-AY VALVE POSITION CHECKLIST

\begin{tabular}{||c|c||}
\hline Valve Designation & Valve Position \\
\hline A-4 (244-S Catch Station) & Route flow from Nozzle 4 to Nozzle 5 \\
\hline DOV SY-102-A (102-SY-02A Pump & $\begin{array}{c}\text { Close by setting FC-SY 102-A to 0\% } \\
\text { Pit) }\end{array}$ \\
\hline A-3 (102-SY-02A Pump Pit) & CLOSED \\
\hline A-1 (102-SY-02A Pump Pit) & Route flow from Valve A-2 to DOV \\
\hline A-2 (102-SY-02A Pump Pit) & CLOSED \\
\hline A-18 (SY-A Valve Pit) & CLOSED \\
\hline A-13 (SY-A Valve Pit) & . \\
\hline A-25 (SY-A Valve Pit) & Route flow from Nozzle L-11 to Nozzle \\
\hline B-15 (SY-B Valve Pit) & Route flow from Nozzle R-19 to Nozzle \\
R-15
\end{tabular}


TK-103-SY TO TK-102-SY VALVE POSITION CHECKLIST

\begin{tabular}{|c|c|}
\hline Valve Description & Valve Position \\
\hline 103-SY-03A Pit & Insta11 Jumper from pump to Nozzle A \\
\hline B-15 (241-SY-B Valve Pit) & $\begin{array}{l}\text { Route flow from Valve R-16 to Nozzle } \\
\text { R-19, Block flow to Valve B-16 }\end{array}$ \\
\hline B-16 (241-SY-B Valve Pit) & $\begin{array}{l}\text { Route flow from Nozzle R-14 to } \\
\text { Nozzle R-11, Block Valve B-15 }\end{array}$ \\
\hline B-25 (241-SY-B Valve Pit) & OPEN \\
\hline B-26 (241-SY-B Valve Pit) & CLOSED \\
\hline A-4 (102-SY-02A Pit) & $\begin{array}{c}\text { Route flow from Nozzle } \mathrm{H} \text { to Tank, } \\
\text { Block Valve A-3 }\end{array}$ \\
\hline A-3 (102-SY-02A Pit) & CLOSED \\
\hline$A-5$ (102-SY-02A Pit) & OPEN \\
\hline
\end{tabular}


WHC-SD-WM-AP-031 REV 0

Leak Detection Equipment

$101 \cdot S Y$

\section{Type}

LIT-101-1

Manual Tape

LDE-01A-A SYS

LDE-02A-1 SYS

LDE-02D-1 SYS

Manual Tape

LIT-101-1

102-SY

LIT-102-1

Manual Tape

LDE-02A-1 SYS

LDE-02D-1 SYS

LDE-VP-SY-A SYS

LDE-VP-SY-B SYS

LDE-V561-SYS

WFR

LDE-V522-SYS

LDE-DB S-151 SY-S

LDE-DB UX-154 SY-S

LDE-ER-151

LDE-ER-153

PS-SN-232

LDE-PP-SYS

PS-SN-215

LDE-241-A-A-VP

LDE-VP241-A-B-1

PS-SN-213

LDE-241-AX-B

LDE-SL-502

LDE-101-20

Manual Tape

LIT-102-AY

\section{Location}

TK-101-SY

TK-101-SY

SY-01A

SY-02A

$S Y-02 D$

TK-102-SY

TK-102-SY
CBRS Description

SY042-2

TK-101-SY Manual Tape

SY046-1

SY022-1

SY041-1

TK-102-SY Manua7 Tape SY089-2

SY089-2

TK-102-SY

TK-102-SY

$S Y-02 A$

$S Y-02 D$

241-SY-A

241-SY-B

$\checkmark-561$

244-S Catch Station

$\mathrm{V}-522$

241-S-151

241-UX-154

241-ER-151

241-ER-153

$\mathrm{SN}-232$

244-A

$\mathrm{SN}-215$

241-A-A

241-A-B

$\mathrm{SN}-213 / 200$

24I-AX-B

$S L-502$

AY -010

TK-102-AY

TK-102-AY
TK-102-SY Manual Tape

SY022-1

SY041-1

SY036-1

SY037-1

$4 \mathrm{~S} 003-1$

SE008-1

4S004-1

SSO01-1

U0006-1

ER320-1

ER340-1

4A034-2

4A017-1

AY193-1

2R072-1

A0242-1

AY189/AY186-1

AX178-1

AY088-1

AY075-1

TK-102-AY Manual Tape AY040-1 
WHC-SD-WM-AP-031 REV 0

\section{$103 \cdot S Y$}

Type

LIT-103-1

Manual Tape

LDE-03A-1 SYS

LDE-02A-1 SYS

LDE-02D-1 SYS

Manual Tape

LIT-102-1
Location

TK-103-SY

TK-103-SY

$S Y-03 A$

SY-02A

$S Y-02 D$

TK-102-SY

TK-102-SY
CBRS Description

SY122-2

TK-103-SY Manual Tape

SY128-1

SY022-1

SY041-1

TK-102-SY Manual Tape

SY089-2 
WHC-SD-WM-AP-031 REV 0

Hydraulic Diagrams, SY Farm 


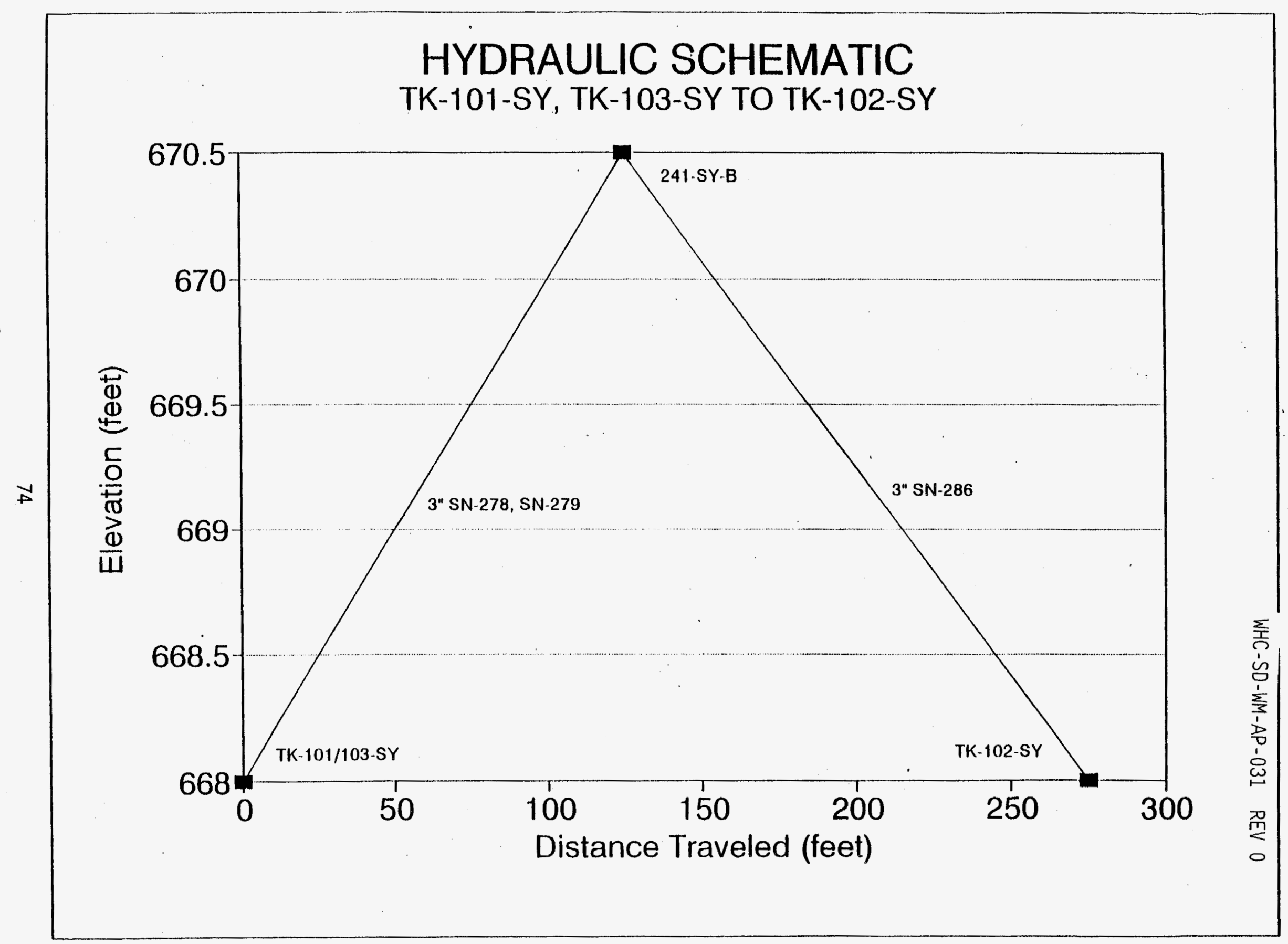




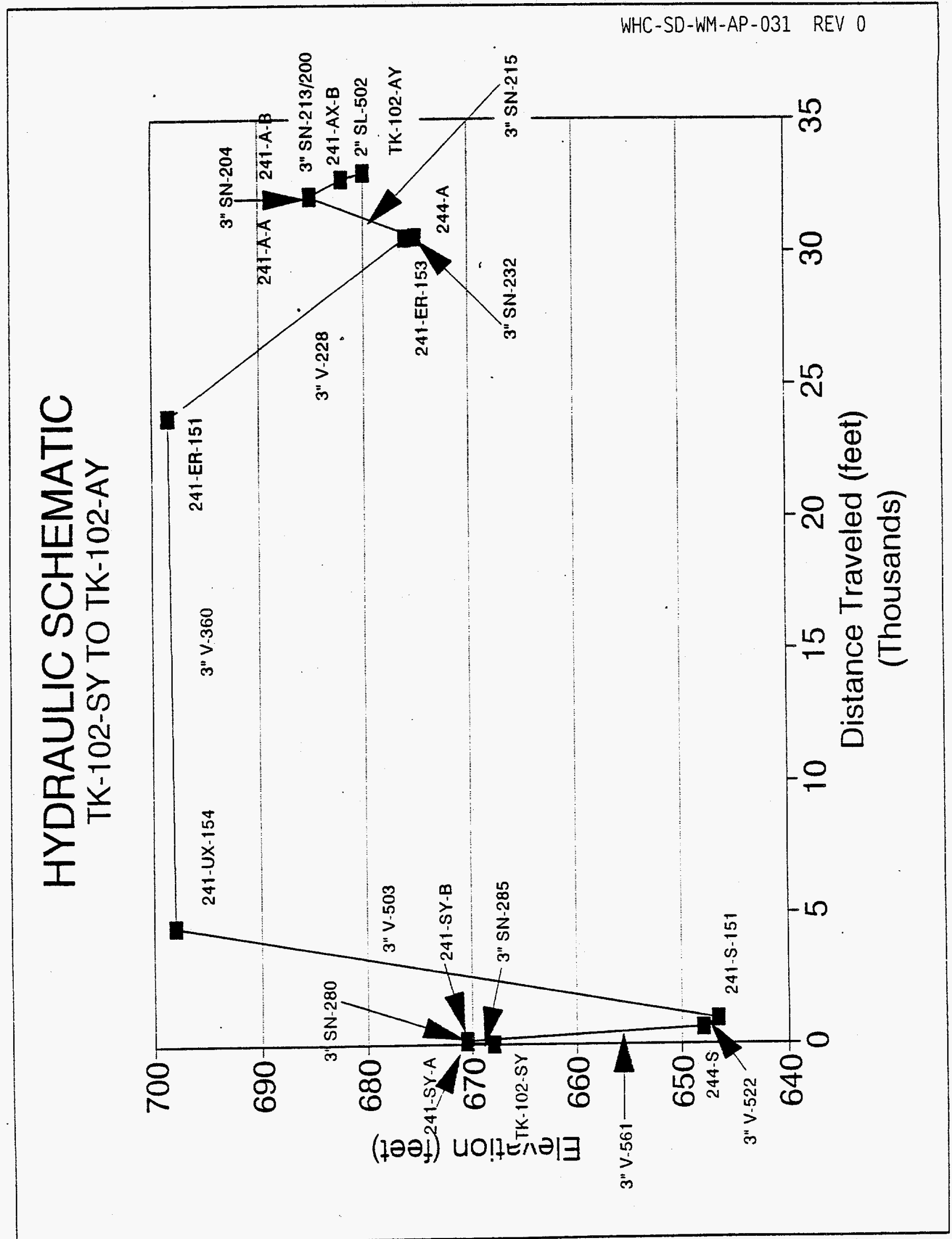




\section{APPENDIX F: Head Loss Calculations}

Calculations for the head loss in the transfer lines are derived from Bernoulii's equation for pipe flow,

$$
P_{1}-P_{2}=\frac{\rho}{144}\left(Z_{2}-Z_{1}+\left(\frac{v_{2}^{2}}{2}-\frac{v_{1}^{2}}{2}\right) \frac{1}{g}+h_{L}\right)
$$

where

$$
\begin{aligned}
& P_{1}, P_{2}=\text { initial and final pressures of the fluid } \\
& \rho=\text { density of the fluid } \\
& Z_{1}, Z_{2}=\text { initial and final heights of the fluid } \\
& v_{1}, V_{2}=\text { initial and final velocities of the fluid } \\
& g=\text { acceleration due to gravity } \\
& h_{L}=\text { head loss (in feet). }
\end{aligned}
$$

Head loss for the system is calculated from the frictional loss, and is defined by the equation

$$
h_{L}=\frac{K}{d^{4}}(0.00259) Q^{2}
$$

where

$$
\begin{aligned}
& Q=\text { fluid flow rate } \\
& d=\text { internal diameter of the pipe } \\
& K=\text { resistance coefficient. }
\end{aligned}
$$

A value for the resistance coefficient can be obtained by using the expression

$$
K=\frac{12}{d} f L
$$


WHC-SD-WM-AP-031 REV 0

for which

$$
\begin{aligned}
& L=\text { length of pipe } \\
& f=\text { friction factor } .
\end{aligned}
$$

The friction factor is based on Reynold's Number, calculated by applying the formula

$$
R e=\frac{Q \rho}{d \mu}(50.6)
$$

where

$$
\mu=\text { viscosity. }
$$

Using the Reynold's number, the friction factor can be found on a chart for fluid flowing through commercial pipe, which is the type of pipe used in the transfer lines. 
WHC-SD-WM-AP-031 REV 0

APPENDIX G: Results of Head Loss Calculations (Currently Installed Pumps)

\begin{tabular}{|c|c|c|c|c||}
\hline Tank & Friction Loss & Elev. Loss & Total Loss & Pump Rating \\
\hline 101 AN & 171 & 12 & 183 & 300 \\
\hline 102 AN & 503 & 12 & 515 & 250 \\
\hline 103 AN & 185 & 12 & 197 & 280 \\
\hline 104 AN & 510 & 12 & 522 & 250 \\
\hline 105 AN & 229 & 12 & 241 & 250 \\
\hline 106 AN & 229 & 12 & 241 & 300 \\
\hline 107 AN & & & & 0 PEN \\
\hline 101 AP & 23 & 0 & 23 & 290 \\
\hline 102 AP & 13 & 0 & 13 & 280 \\
\hline 103 AP & 23 & 0 & 23 & 240 \\
\hline 105 AP & 39 & 0 & 39 & 220 \\
\hline 106 AP & 37 & 0 & 37 & 250 \\
\hline 107 AP & 45 & 0 & 45 & 250 \\
\hline 108 AP & 47 & 0 & 47 & 250 \\
\hline \hline 101 AW & 24 & -8 & 16 & 300 \\
\hline 102 AW & 20 & -8 & 12 & 280 \\
\hline 103 AW & 25 & -8 & 17 & 300 \\
\hline 104 AW & 25 & -8 & 17 & 300 \\
\hline 105 AW & 30 & -8 & 22 & 300 \\
\hline 106 AW & 26 & -8 & 18 & 280 \\
\hline 101 SY** & & 12 & & $0 P E N$ \\
\hline 102 SY* & 321 & 12 & 333 & 340 \\
\hline 103 SY** & 8 & 12 & 20 & 115 \\
\hline 101 AY & 71 & -4 & 67 & 115 \\
\hline 102 AY & 46 & -4 & 42 & 300 \\
\hline
\end{tabular}

*The data for this pump is based on transfer to TK-102-AY

**These pumps transfer to TK-102-SY 
WHC-SD-WM-AP-031 REV 0

APPENDIX H: Calculated Head Losses for Standard Pipe Flow Rates

\begin{tabular}{||c|c|c|c|c||}
\hline Tank & $\begin{array}{c}\text { Loss a 50 GPM } \\
\text { (FEET) }\end{array}$ & $\begin{array}{c}\text { LoSs a 100 } \\
\text { GPM (FEET) }\end{array}$ & $\begin{array}{c}\text { Loss @ 125 } \\
\text { GPM (FEET) }\end{array}$ & $\begin{array}{c}\text { LOSS Q 150 } \\
\text { GPM (FEET) }\end{array}$ \\
\hline 101 AN & 78 & 245 & 382 & 534 \\
\hline 102 AN & 77 & 243 & 369 & 517 \\
\hline 103 AN & 77 & 246 & 368 & 517 \\
\hline 104 AN & 76 & 249 & 376 & 524 \\
\hline 105 AN & 77 & 243 & 371 & 520 \\
\hline 106 AN & 77 & 243 & 371 & 520 \\
\hline 107 AN & 78 & 250 & 374 & 525 \\
\hline \hline 101 AP & 4.5 & 16.3 & 25.0 & 35.5 \\
\hline 102 AP & 4.6 & 16.6 & 25.6 & 36.4 \\
\hline 103 AP & 3.8 & 13.8 & 21.1 & 29.9 \\
\hline 105 AP & 5.7 & 20.6 & 31.7 & 44.9 \\
\hline 106 AP & 4.1 & 14.8 & 22.5 & 32.2 \\
\hline 107 AP & 4.5 & 16.4 & 25.3 & 35.9 \\
\hline 108 AP & 4.7 & 17.0 & 26.1 & 37.2 \\
\hline 101 AW & 13.2 & 34.2 & 49.2 & 69.2 \\
\hline 102 AW & 11.2 & 29.2 & 43.2 & 59.2 \\
\hline 103 AW & 13.2 & 35.2 & 49.2 & 70.2 \\
\hline 104 AW & 13.7 & 35.6 & 51.8 & 71.2 \\
\hline 105 AW & 13.6 & 35.2 & 51.9 & 70.6 \\
\hline 106 AW & 14.1 & 37.1 & 53.5 & 74.4 \\
\hline 101 SY & 14 & 19 & 24 & 29 \\
\hline 102 SY & 235 & 828 & 1274 & 1777 \\
\hline 103 SY & 14 & 20 & 24 & 29 \\
\hline 101 AY & 36 & 134 & 198 & 275 \\
\hline 102 AY & 28 & 106 & 162 & 230 \\
\hline \hline
\end{tabular}


WHC-SD-WM-AP-031 REV 0

APPENDIX I: Calculated and Measured Head Loss vs. Flow Values for 102-AN and 104-AN 


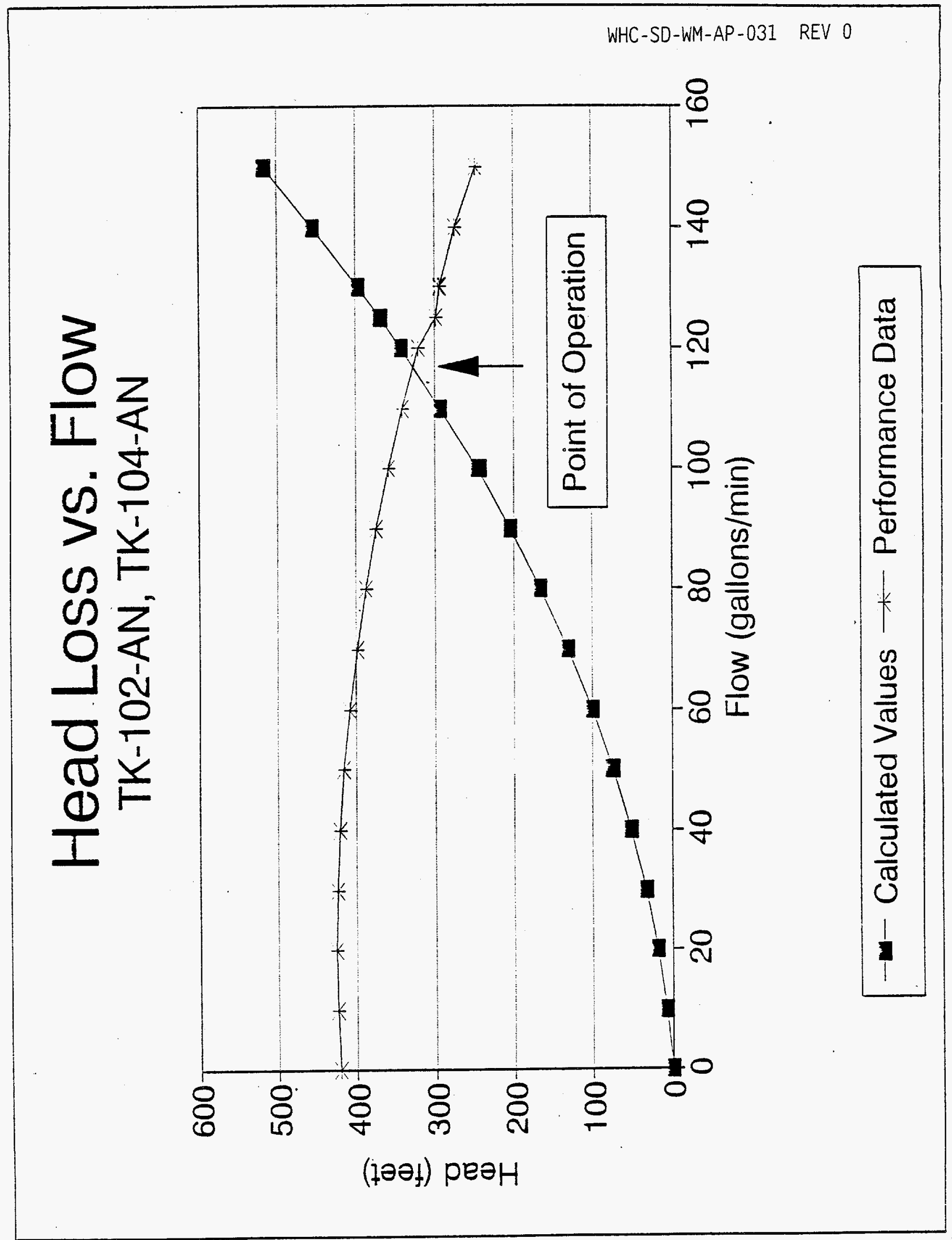


WHC-SD-WM-AP-031 REV 0

APPENDIX J: Other Interconnected Tanks

\section{TANK}

A-350-CT

S-302-A CT

311-ER CT

UX-302A CT

\section{CBRS INFORMATION}

WFT-350-1, AE073-4

LDE-S-302A S-YS, S3002-1

LDE-ER-311 SY-S, ER302-1

LDE-UX 30-2A SYS, UX302-1
CONNECTED TO

241-A-A, 241-A-B

241-S-151

241-ER-151

$241-U X-154$ 